\title{
Biosorption: A Review of the Latest Advances
}

\author{
Enrique Torres \\ Laboratorio de Microbiología, Facultad de Ciencias, Universidade da Coruña, Campus de A Zapateira, \\ 15071 A Coruña, Spain; enrique.torres@udc.es; Tel.: +34-981-167-000; Fax: +34-981-167-065
}

Received: 14 September 2020; Accepted: 27 November 2020; Published: 1 December 2020

Abstract: Biosorption is a variant of sorption techniques in which the sorbent is a material of biological origin. This technique is considered to be low cost and environmentally friendly, and it can be used to remove pollutants from aqueous solutions. The objective of this review is to report on the most significant recent works and most recent advances that have occurred in the last couple of years (2019-2020) in the field of biosorption. Biosorption of metals and organic compounds (dyes, antibiotics and other emerging contaminants) is considered in this review. In addition, the use and possibilities of different forms of biomass (live or dead, modified or immobilized) are also considered.

Keywords: biosorption; biomass; bioaccumulation; biocomposite; pollutants; metals; emerging organic contaminants; dyes

\section{Introduction}

Biosorption is a variant of the sorption techniques in which the sorbent is a material of biological origin. Today, biosorption is considered a simple, economical and environmentally friendly process that is used as an attractive alternative for removing pollutants. Within this context, biosorption is a general term that describes the removal of pollutants by their binding to a material of biological origin (biomass). There have been numerous biosorption studies in the last decade, and advances in this field have reinforced the interest in this technique to solve environmental pollution problems. The existing information on biosorption is abundant due to the large number of works that are published to test the validity of certain materials as biosorbents or to develop more complex hybrid materials that can be more efficient for this purpose. This review aims to evaluate the latest contributions (in the last couple of years: 2019-August 2020) in the field of biosorption. Although biosorption is a mechanism that also acts in soil decontamination, this review will focus on biosorption processes from aqueous solutions.

\section{Biosorption: Generalities}

The main element of a biosorption process is biomass. The term biomass is a very broad term that includes intact living cells and derived compounds of biological origin with different degrees of transformation (waste, charcoal, etc.). Taking this into account, the use of biological materials as sorbents has an important alternative: this biomass can be alive or dead. In the case of dead biomass, the pollutants passively (metabolism-independent) bind to this type of biomass through ionic, chemical or physical mechanisms (biosorption); however, with living biomass, the process is more complex because the metabolic activity of this biomass is added to the passive mechanisms. This metabolic activity allows the active transport of pollutants through the membrane into the cell interior. In this way, pollutants can accumulate inside the cell (bioaccumulation). Furthermore, since the enzymatic activity is preserved in living biomass, there is also the possibility that different enzymatic activities may alter the state of the pollutant (biodegradation and biotransformation).

Considering the previous information, the use of living biomass as a biosorbent would have more possibilities to remove a greater amount of pollutants, which constitutes an important advantage when 
using this type of biomass. However, other advantages and disadvantages must be considered in the use of one type or another of biomass. Most applications focus on the use of dead biomass because toxicity related problems are avoided, no maintenance is required, this biomass can be stored for long periods without loss of effectiveness, regeneration is more feasible and it is possible to work on a greater range of environmental variables. In addition, this biomass can be cut and ground to obtain a suitable particle size. However, despite all these advantages of dead biomass, the use of living biomass can have an important advantage, since, as indicated above, the cells are metabolically active, so the pollutants can be incorporated into the cell interior increasing the efficiency of the process because bioaccumulation contributes to the initial biosorption process [1,2]. In this case, there would be a first step, independent of metabolism, in which the pollutant would bind to the cell surface (biosorption in the strict sense), and a second step, dependent on metabolism, in which the pollutant is transported through the cell membrane to the cell interior. At this step, it must be taken into account that some pollutants could also pass through the membrane by passive diffusion. In many cases, the term biosorption is used in a general way to include both steps when using living systems, although both steps are different.

Continuing with the advantages and disadvantages of living biomass, an additional advantage that active systems have is that there is also the possibility of biotransformation or biodegradation, increasing, in some cases, the ability to eliminate a higher amount of pollutant [3-7]. However, there are also disadvantages that can be attributed to the use of living biomass. Thus, it must be considered that to use living biomass it is necessary to have culture systems, nutrient supply and some method for cell harvesting, which makes the process more expensive. However, dead biomass can also have additional costs, since, in some cases, this type of biomass is chemically modified, carbonized or ground to make it more effective, which does not apply to living biomass. Additionally, living biomass is easier to separate from a reaction system.

In any case, an important aspect to consider in order to achieve the advantages of living biomass can be effective is to look for those organisms that show greater resistance to the toxic effects of the pollutant. Hence, this is a first step to optimize a biosorption/bioaccumulation process using living biomass. Strains more resistant to the target pollutant can have a greater removal capacity; a recent example is the use of a strain of Pseudomonas sp. with resistances to multiple heavy metals for cadmium removal; this resistant strain used as living biomass was more effective than the dead one [8]. In this sense, there is currently a growing interest in the use of microorganisms as base material to develop biosorbents due to their good sorption properties and resistance to the toxic effect of pollutants. Various species of fungi, bacteria, yeast and microalgae have been tested against many types of pollutants with very promising results $[4,8-13]$.

In addition to biomass from microorganisms, as indicated above, a large number of materials have been evaluated as biosorbents to eliminate different pollutants, among the most recent are: agro-industrial waste materials [14], sludge [15,16], polysaccharides [17], plant-derived materials [18-20] and biopolymers [21]; although it is necessary to indicate that throughout the years of development of biosorption, a large number of biological materials of very diverse origin have been evaluated as possible biosorbents [22,23]. Many of these materials are considered as waste: for this reason, the use of these materials as biosorbents has a double advantage, on the one hand, a waste is used for an application, and therefore, its waste is reduced; on the other hand, this material is used to eliminate pollution with a possible low cost.

These biomaterials can be applied directly or immobilized on different supports. Recently, there has been an increase in the number of studies applying biomaterials packed in fixed-bed columns [24,25]. This technique offers advantages for practical applications of large-scale biosorption processes because it allows continuous work. Thus, to operate with these columns, the biomass must be immobilized, which is necessary when using biomass from microorganisms. A common alternative (which can even be used with living cells) is to immobilize the biosorbent in a calcium alginate matrix [6,26,27]. Immobilization allows the biomass to be retained in a reactor, reduces separation costs and increases the 
mechanical resistance of the biomass. In this context, although biosorption/bioaccumulation techniques are usually simple, more complex systems have now been developed, forming biocomposite materials with new characteristics. These materials with polymeric structures allow to protect and maintain the viability of living systems, which makes it possible to take advantage of the highest efficiency of these systems. An example of this was the use of biomass from Lysinibacillus sphaericus CBAM5 immobilized in polycaprolactone microfibrous mats and alginate microcapsules to capture gold from synthetic water samples [28]. Although the application of nanoparticles in the field of biosorption has been developing for a long time, more recently the application of magnetic nanoparticles as a support for the immobilization of microorganisms has also been assessed, as evidenced in the review by Giese et al. (2020) [29].

Another way to use biomass is by its chemical modification to increase the sorption capacity. These modifications alter the functional groups of the biomass and its surface topography favoring the binding of pollutants. Some examples have recently been published in which different modification methods are used, such as esterification, graft polymerization, coating, treatments with acids, alkalis, methanol, cationic surfactants, formaldehyde or triethyl phosphate and nitromethane [30-33]. Although these modifications apply to dead biomass, living biomass can also be modified, but in a very different way, by genetic modification, which allows the introduction of genes into the desired biomass that increase resistance to the toxic effect of certain pollutants, or that increase the uptake of the pollutant (several examples with metals have recently been published) [34-36].

Although biosorption alone is an effective technique, its flexibility allows coupling with other techniques. For example, biosorption allowed to replace expensive materials used in anodic oxidation processes with plant material [37]; in this way, hybrid materials are created increasing the efficiency of biosorption [38].

Since biosorption requires an interaction between the biomass and the pollutant (usually multiple interactions coexist), those factors that influence this interaction will influence the efficiency of the process. Interactions such as ion exchange, complexation/coordination, electrostatic interactions, chemisorption, physisorption, microprecipitation and reduction can be established in a biosorption process. Taking this into account, factors such as $\mathrm{pH}$, temperature (thermodynamic studies), contact time, shaking speed, initial concentration of the pollutant or amount of biosorbent are well known and are evaluated to optimize the biosorption process [23]. However, there are other less studied factors that have an impact on the process-for example, the type and amount of functional groups in the biomass such as carboxyl, amino, phosphoryl or sulfonate and that influence the biosorption of some pollutants (mainly metals) [9,31,39], ionic strength [40], presence of dissolved organic matter that alters the absorption of metals [41] or the competition with other pollutants $[40,42,43]$. When using a living system, it is necessary to consider other factors such as the response to the possible toxicity of the pollutant $[44,45]$.

It is evident that the nature of the biosorbent determines many of its physico-chemical properties, such as the type and quantity of functional groups, but there are other aspects that are also especially relevant in the process, such as surface area (increasing the surface area increases the contact of the sorbate with the sorbent), porosity (mesoporosity increases the biosorption capacity, while microporosity decreases it) or cell structures (different structures have different physico-chemical characteristics) $[39,46,47]$. The characterization of the material in terms of its morphology and composition are common in biosorption studies because they allow a more detailed description and provide information on the sorption mechanisms. Fourier transform infrared spectroscopy (FTIR), scanning electron microscopy (SEM) and energy dispersive x-ray spectroscopy (EDS) are methods commonly used for this purpose. Thermogravimetric test, elemental analysis, zeta potential and point of zero charge ( $\mathrm{pHzpc}$ ) measurement are alternative parameters that also provide information on the physico-chemical characteristics of the biosorbent. Recently, an electrokinetic method termed as dielectrophoresis (DEP) was applied for the characterization of biosorption [48]. 
Kinetic and isotherm models are used for the mathematical modeling of the biosorption processes. Traditionally, the most widely used kinetic models are pseudo-first order [49], pseudo-second order [50] and intraparticle [51]. From these models, different parameters are obtained that allow characterizing the speed of the process, time to reach equilibrium or even determine which stages of the process may be limiting. Currently there are other kinetic models that are being used and that are useful to characterize biosorption processes such as the kinetics Brouers-Sotolongo family model [38,52]. Regarding the isotherm models, the Langmuir [53] and Freundlich [54] models are still the most widely used.

The search and evaluation of new biosorbents is a current challenge in this field. These new biosorbents must be more efficient, economical and have good reusability through various application cycles. Although this last property is desired for many sorbents, in the case of biosorbents (used as dead biomass) it can be considered non-essential because, precisely, a property of these materials must be their low cost. Instead, it is important that these materials prove their worth under real application conditions.

Everything said above shows the great interest in applying biosorption-related techniques to solve pollution problems. However, the interest of biosorption goes beyond its usefulness as a pollutant remover: biosorption techniques even allow the recovery of some useful substances. Since many of the mechanisms involved in biosorption are reversible, there is the possibility of recovering the biosorbed materials, and at the same time regenerating the biosorbent. An example of this application is the rare-earths recovery: these high-value elements can be effectively recovered using biosorption techniques as an alternative to the conventional unit operations of extractive metallurgy [55].

Today, the validity of biosorption, with all its advantages, is more than demonstrated; the great challenge is to apply this technique to more real situations. In the vast majority of studies, the biosorption process is carried out in distilled water, where the pollutants to be tested are solubilized, and there are few examples where biomass is applied to more real situations [56,57].

\section{Biosorption of Metals}

Metal biosorption is among the most studied applications of this technique. In fact, the first applications of biosorption focused on metal removal [58,59]. For decades, metals have been a serious environmental problem due to human activity [60-62]. For this reason, the development of techniques that allow their removal has been a priority. Biosorption is a very effective, economical and environmentally friendly technique to remove these pollutants, and at present, different methods have been evaluated based on biosorption [22,63].

Ion exchange is the predominant mechanism for metal biosorption along with surface complexation and microprecipitation $[46,55,64]$. Various functional groups are involved in the biosorption of metals, carboxyl, hydroxyl, sulfate, phosphoryl and amino groups [31]. Because of this, $\mathrm{pH}$ has an important effect on the biosorption of metals. The $\mathrm{pH}$ affects the charge of these functional groups and, therefore, the amount of biosorbed metal. Since cationic species are among the predominant forms of most metals in aqueous solution, the more negative charge the biosorbent has, the greater the amount of biosorbed metal. For this reason, the most suitable $\mathrm{pH}$ range for metal biosorption is 7.0-8.0. At lower $\mathrm{pHs,}$ hydrogen ions and metal ions compete for binding sites; and at higher $\mathrm{pHs}$, there is precipitation of metal ions in the form of hydroxides, reducing the amount of biosorbed metal. However, this behavior is different for the case of some metals whose predominant forms are anionic, such as chromium, arsenic or molybdenum, among others. In this case, acidic pHs (2.0-4.0) are the most favorable for increasing biosorption because at these $\mathrm{pHs}$ the biomass has a greater number of positive charges, which allows the attraction of anions.

Although $\mathrm{pH}$ is considered a key factor in this process, temperature also influences biosorption since this parameter affects the rate of reactions. Higher temperatures usually enhance biosorption rate due to the increase in surface activity and kinetic energy of sorbate [65]. However, its effect on the maximum amount of biosorbed metal is debatable. It is generally accepted that the increase in 
temperature increases the maximum amount bioasorbed, which occurs when the process is endothermic, and is due to various factors such as structural changes in the sorbent or breakdown of bonds between the sorbent molecules; however, there is also some exceptions, which take place when the process is exothermic. In this case, there is a decrease in biosorption capacity with an increase in temperature, possibly due to damage caused to the surface of the biosorbent [30,66,67]. With dead biomass, this effect of temperature is less apparent than with living biomass. With living biomass, as the temperature increases, the amount of biosorbed metal increases more appreciably than in the case of dead biomass [68,69]. The reason is the greater metabolic activity of living cells when the temperature increases until an optimum value, causing the metal to be incorporated in a higher amount into the cell interior. When the temperature exceeds the optimum value, the living material is damaged and the biosorption decreases to a greater extent in relation to the dead biomass [27]. Finally, an increase in ionic strength reduces the amount of biosorbed metal due to competition of other cations for the binding sites on the functional groups [70]. This is a major drawback when applying biosorbents in real effluents that are often characterized by complex concentrations of different cations.

Precisely, materials derived from biomass are characterized by offering a large and diverse number of functional groups that interact with metals (carboxyl, hydroxyl, sulfate, phosphoryl and amino groups, as indicated above), which explains the good performance of these materials as biosorbents in metal removal. Of special interest is biomass derived from algae because it has a relatively high adsorption efficiency of 1-10 g/L [71]. As an important additional property, biomass derived from microorganisms can be easily genetically modified to increase the biosorption capacity. This strategy is receiving a lot of attention recently to increase metal removal. Thus, the expression of the EC20 protein (a synthetic phytochelatin) on the surface of various bacteria was used in $\mathrm{Pb}, \mathrm{Zn}, \mathrm{Cu}, \mathrm{Cd}, \mathrm{Mn}$, $\mathrm{Ni}$ and, recently, in Pt biosorption [34]. In the same way, the expression of a non-MT cadmium-binding protein from Lentinula edodes significantly enhanced the cadmium biosorption capacity of transgenic Escherichia coli [35]. The transformation of the wild-type Saccharomyces cerevisiae with two versions of a Populus trichocarpa gene (PtMT2b) coding for a metallothionein allowed an increase in the intracellular content of cadmium in relation to the wild strain [36].

Another aspect to take into account when applying biosorption to metal removal is that biosorption not only serves to remove these elements but also allows their recovery, which increases interest in this process [72]. This application can be extended to an industrial scale, for which the sorbent must have adequate properties. Precisely, one of the interesting properties of biomass is that it can be easily modified to adapt it to commercial and industrial uses [73].

Metal biosorption studies cover most commonly used metals, but metals considered non-essential are the ones that have received the most attention. Numerous studies on metal removal continue to be carried out today using different biosorbents.

\subsection{Chromium (VI)}

Chromium is the metal that has received the most attention lately for its removal through biosorption (Table 1). 
Table 1. Recent chromium (VI) biosorption studies using different biomasses.

\begin{tabular}{|c|c|c|c|c|c|}
\hline Biomass & $\begin{array}{c}\text { Chromium } \\
\text { Concentration }(\mathrm{mg} / \mathrm{L})\end{array}$ & Contact Time (min) & Efficiency (mg/g) & Remarks & Reference \\
\hline $\begin{array}{l}\text { Waste biomass from polyglutamic } \\
\text { acid production }\end{array}$ & $50-400$ & 60 & 2.39 & $\begin{array}{l}\text { Immobilized in } \\
\text { sodium alginate }\end{array}$ & [74] \\
\hline Date palm empty fruit bunch & $50-250$ & 120 & 70.49 & Batch studies & [75] \\
\hline Datura stramonium fruit & $100-300$ & 60 & 138.074 & $\begin{array}{l}\text { Carbonized form of } \\
\text { sulfuric and } \\
\text { phosphoric } \\
\text { acid-treated biomass }\end{array}$ & [76] \\
\hline Halomonas sp. DK4 & $50-250$ & 2880 & 150.7 & Batch studies & [77] \\
\hline Zhihengliuella sp. ISTPL4 & $50-500$ & 1440 & $49 \pm 0.3$ & $\begin{array}{l}\text { Calcite-based } \\
\text { biocomposite biochar }\end{array}$ & [78] \\
\hline Coconut fibers & 100 & 20 & 87.38 & $\begin{array}{l}\text { Magnetized using } \\
\text { magnetite nanoparticles }\end{array}$ & [14] \\
\hline Quercus crassipes acorn shell & $50-400$ & - & 110.35 & Fixed-bed column & [79] \\
\hline Leiotrametes flavida & 1000 & 1200 & 285 & $\begin{array}{l}\text { Live and } \\
\text { heat-inactivated }\end{array}$ & [80] \\
\hline Sargassum horneri & $100-600$ & 360 & 330.84 & $\begin{array}{l}\text { Polyethyleneimine-modified } \\
\text { ultrasonic assisted } \\
\text { acid hydrochar }\end{array}$ & [81] \\
\hline Pteris vittata & $100-250$ & 120 & 166.7 & Dead, unmodified & [82] \\
\hline Synechococcus mundulus & $75-175$ & 2880 & $\begin{array}{ll}- & 85.89 \% \\
- & \text { Initial Cr(VI) concentration } \\
\text { of } 300 \mathrm{mg} / \mathrm{L}\end{array}$ & $\begin{array}{l}\text { Extruded polymeric } \\
\text { substances secreted } \\
\text { under the effect of } \\
\text { 2-KGy gamma } \\
\text { irradiation dose }\end{array}$ & [17] \\
\hline Agaricus campestris & $10-100$ & 200 & 56.21 & $\begin{array}{l}\text { Unmodified } \\
\text { dead biomass }\end{array}$ & [83] \\
\hline Pleurotus ostreatus & $10-150$ & 22 & $\begin{array}{ll} & \text { Living biomass: } 169.84 \\
\text { - } & \text { Dead biomass: } 368.21\end{array}$ & $\begin{array}{l}\text { Living and } \\
\text { dead biomass }\end{array}$ & [84] \\
\hline Pseudomonas sp. strain DC-B3 & $10-135$ & 420 & 25.64 & Living cells & [85] \\
\hline Kodamaea transpacifica & $10-100$ & 240 & 476.19 & $\begin{array}{l}\text { Cationic } \\
\text { surfactant-modified } \\
\text { living cells }\end{array}$ & [86] \\
\hline Parapedobacter sp. ISTM3 & $10-200$ & 15 & 33.78 & $\begin{array}{l}\text { Extracellular } \\
\text { polymeric substances }\end{array}$ & [87] \\
\hline Eupatorium adenophorum & $10-300$ & 60 & 28.011 & $\begin{array}{l}\text { Calcium } \\
\text { alginate entrapped }\end{array}$ & [26] \\
\hline
\end{tabular}

As can be seen in this table, the biological materials that have been evaluated are very diverse and show very good efficiency. The strategies using these different biomasses were also very varied since they range from typical batch experiments to continuous flow systems, immobilization techniques or more sophisticated modifications of the biomass, which demonstrates the versatility of biosorption.

The main mechanisms involved in the biosorption of $\mathrm{Cr}(\mathrm{VI})$ are related to electrostatic attraction, surface complexation and heterogeneous redox reaction to form $\mathrm{Cr}(\mathrm{III})$ ions [75]. In addition, in chromium biosorption processes, it is necessary to consider that this metal, unlike most metals, is in the form of anions. This means that the behavior towards biosorbents is different. In this case, the range of pHs considered optimal to carry out biosorption is $2.0-3.0[14,26]$. At low $\mathrm{pHs}$, the biomass surface is highly protonated, offering a large amount of positive charges that attract chromium anions. Obviously, this $\mathrm{pH}$ range cannot be used with living biomass; however, the biological activity of this type of biomass can compensate for this inconvenience, especially using resistant strains [85]. This behavior can be applied to other metals such as dysprosium [88], arsenic [89] or tungsten [20].

\subsection{Cadmium (II)}

Cadmium is among the metals that has received the most attention from the biosorption field. Today, there are still studies related to this non-essential metal. Thus, living and dead biomass of Pseudomonas sp. strain 375 was tested for cadmium removal. Living biomass was more effective $(92.59 \mathrm{mg} / \mathrm{g})$ than dead biomass $(63.29 \mathrm{mg} / \mathrm{g})$ [8]; it is a strain with great resistance to cadmium toxicity, and for this reason, the living form of this biomass surpassed the dead one in efficiency, demonstrating the interest in testing the use of living systems in this type of applications. Another example of the utility of using living systems was the application of Pseudomonas chengduensis strain MBR as living biomass. This strain was able to remove $100 \%$ of $\mathrm{Cd}(\mathrm{II})$ (with a high initial 
concentration of $200 \mathrm{mg} / \mathrm{L}$ ) due to a combination of biosorption and biotransformation. This strain has many functional genes related to heavy metal resistance in its genome which would explain this result [3].

In general, metal tolerant strains show better efficiencies in biosorption of these elements when living biomass is used; for example, living cells of a lead resistant strain of Staphylococcus aureus were more efficient for the biosorption of cadmium and lead than dead biomass [44]. This shows that it is very important to screen suitable strains for this purpose [90].

Unlike dead biomass, metabolically active cells can bioaccumulate metal inside the cell, which increases the amount of removed metal. At the same time, this type of biomass can transform the pollutant into non-toxic forms, which is important in practical applications. A similar result was obtained with a cadmium-tolerant bacterium, Enterobacter ludwigii LY6: the cadmium chloride removal rate of this strain with a treatment of $100 \mathrm{mg} / \mathrm{L}$ of cadmium chloride reached $56.0 \%$. In this strain, the expression of several genes closely related to bacterial cadmium tolerance and biosorption increased with the increase in the cadmium concentration [91]. Taking this into account, genetic modification is also a very useful tool to achieve resistant strains that can be used as living biomass, and therefore, with better biosorption capacity. Several examples show the effectiveness of this strategy. The deletion of the crpA gene (P-type ATPase) in the fungus Aspegillus nidulans showed 2.7 times higher cadmium biosorption capacity [92]. A transgenic yeast that expressed a metallothionein gene from Populus trichocarpa had higher intracellular $\mathrm{Cd}$ than the wild strain [36]. Through genetic engineering, a plant cadmium and zinc transporter (AtHMA4) was also used as a transgene to increase tolerance to these metals and the biosorption capacity of Chlamydomonas reinhardtii [93].

Most studies indicate that the tightly bound cadmium on the cell wall plays a major role in $\mathrm{Cd}^{2+}$ adsorption [8,90]. Thus, cadmium biosorption studies with the Simplicillium chinense QD10 strain [94] and with Shewanella putrefaciens [95] used as living cells suggested that the cell wall components were the primary interactive targets for this metal. Cadmium sulfide nanoparticles can also form on the cell surface, which contributes to the excellent tolerance to this metal of E. ludwigii LY6 [91]. Additionally, on the cell surface, the exopolysaccharides (EPS) might be the main means of cadmium adsorption by some strains [91].

Another recently used approach to increase the efficiency of cadmium removal was the use of grapefruit (Citrus paradisi) peel treated with $\mathrm{Ca}^{2+}$ or $\mathrm{Mg}^{2+}$. Through these modifications, increases of 46.3 and $27 \%$, respectively, were achieved in the amount of cadmium removed by this biomass, demonstrating that this residue with a simple modification can be useful as a cadmium biosorbent [96]. A novel composite, which was synthesized by Bacillus sp. K1 loaded onto $\mathrm{Fe}_{3} \mathrm{O}_{4}$ biochars, presented a $230 \%$ increase in the capacity to remove cadmium compared to raw magnetic biochar [89]. This is one more demonstration of the importance of materials of biological origin in sorption processes.

The Pediococcus pentosaceus FB145 and FB181 strains, which can be considered as probiotic microorganisms, were suggested as potent biosorbents for preventing cadmium toxicity and reducing its absorption into the human body [97]—one more utility of biosorption, in this case, directly related to human health.

\subsection{Lead (II)}

Lead is another non-essential element that recently attracted greater attention from the field of biosorption. A new proposal to improve the biosorption of this element by fungal biomass was developed using the biomass of Phanerochaete chrysosporium with an intracellular mineral scaffold. The intracellular mineral scaffold of this functionalized biomass served as an internal metal container exhibiting high biosorption efficiency for $\mathrm{Pb}(\mathrm{II})$ and $\mathrm{Cd}$ (II) ions [98]. A comparative study using different biomass of microorganisms (Pseudomonas putida I3, Microbacterium sp. OLJ1 and Talaromyces amestolkiae) showed that the different cell structure had a clear influence on the efficiency of lead biosorption. The most efficient biomass was Pseudomonas putida I3 with $345.02 \mathrm{mg} / \mathrm{g}$. These biosorbents were tested 
in real wastewater, revealing that these biosorbents possessed good environmental adaptability and great potential for the removal of trace heavy metals from wastewater in practical application [46].

Live and dead biomass of a highly $\mathrm{Pb}$ (II) resistant (up to $2200 \mathrm{mg} / \mathrm{L}$ ) bacterium (Bacillus xiamenensis) were also tested for biosorption of this ion. The maximum $\mathrm{Pb}$ (II) uptake was 216.75 and $207.4 \mathrm{mg} / \mathrm{g}$ for live and dead biomass, respectively [99]. Again, the living and active biomass of a resistant strain showed better performance (intracellular accumulation of lead ions was detected). Living and dead biomass of a (Pb)-resistant bacterium, Staphylococcus hominis strain AMB-2 was also evaluated for lead and cadmium removal. Living biomass exhibited more biosorption of metals than dead biomass in both single and binary systems; moreover, lead had a higher affinity for the binding sites on the biomass surface [44]. However, a different result was obtained using living and dead biomass of Rhodococcus sp. HX-2. In this case, the dead biomass was more effective. The maximum biosorption capacities were 88.74 and $125.5 \mathrm{mg} / \mathrm{g}$ for live and dead biosorbents, respectively. In this case, $\mathrm{Pb}$ (II) adhered to the surface of dead biosorbents more easily than to the surface of live biosorbents [68]. The characteristics of the cell surface also affect the amount of lead removed because, in addition to biosorption, this ion can be mineralized [100].

Biomass from the Simplicillium chinense fungus strain QD10 had a maximum biosorption capacity of $57.8 \mathrm{mg} / \mathrm{g}$. In this strain, the lead biosorption was predominantly adsorbed by extracellular polymeric substances [101].

Other biomasses that were also recently tested for lead biosorption were Moringa oleifera leaves (maximum biosorption of $45.83 \mathrm{mg} / \mathrm{g}$ ) [102] and the lactic acid bacterium Lactobacillus brevis used as living biomass with a maximum biosorption of $53.63 \mathrm{mg} / \mathrm{g}$ [69]. Cotton (Gossypium hirsutum) shell powder was used as a biosorbent for the treatment of synthetic Pb-contaminated water. This biomass reached a biosorption capacity of $9.6 \mathrm{mg} / \mathrm{g}$ [103].

\subsection{Mercury (II)}

Mercury is another of the non-essential elements that recently had some study from the point of view of biosorption. Different tests show the application of this technique to remove this metal. A biopolymer consisted of proteins, carbohydrates and nucleic acids from waste activated sludge was evaluated. This biopolymer had a maximum adsorption capacity up to $477.0 \mathrm{mg} \mathrm{Hg}(\mathrm{II}) / \mathrm{g}$ [21]. Algal biomass (Chlorella vulgaris UTEX 2714) was also tested for remove $\mathrm{Hg}$ (II). This biomass used as dead biomass presented a rapid kinetics of adsorption (90 $\mathrm{min}$ ) and with a capacity of $42 \mathrm{mg} / \mathrm{g} \mathrm{[104]}$. In addition, this biomass presented a good regeneration: this property is important for a biosorption process to be viable.

Living systems were also recently used to remove mercury. Living biofilm, developed on a non-woven polypropylene and polyethylene geotextile was tested. This biomass removed $13.34 \mathrm{mg} / \mathrm{g}$ in 28 days [105].

\subsection{Uranium (VI)}

Uranium is another element that has recently received attention from the field of biosorption. This metal is a major health problem; therefore, the development of applications for its removal shows considerable interest. Different biomasses have recently been successfully evaluated for this purpose; of these biomasses stands out Saccharomyces cerevisiae. Dead biomass of this yeast removed uranium efficiently due to the large number of functional groups that this biomass presents [31]. This same species, immobilized by a new method based on saturated boric acid-alginate calcium cross-linking, had a biosorption capacity of $113.4 \mu \mathrm{mol} / \mathrm{g}$ [106].

Living biomass of the resistant bacterium, Bacillus amyloliquefaciens had a maximum uptake capacity of $179.5 \mathrm{mg} / \mathrm{g}$ [45]. Similarly, biomass from the macrophytes Pistia stratiotes and Lemna sp. presented a maximum uranium sorption capacity of $2.86 \times 10^{-2}$ and $6.81 \times 10^{-1} \mathrm{mmol} / \mathrm{g}$, respectively, with an optimum contact time of $60 \mathrm{~min}$ [107]. 
Sorbent modification has been a widely used method to increase the efficiency of uranium removal. This method is also applicable when biomass is used. Tri-amidoxime modified marine fungus material had a uranium biosorption capacity of $584.60 \mathrm{mg} / \mathrm{g}$ with good regeneration performance. The unmodified biomass originally had a capacity of only $15.46 \mathrm{mg} / \mathrm{g}$ [108]. The macroporous ion-imprinted chitosan foams showed an adsorption capacity of $248.9-253.6 \mathrm{mg} / \mathrm{g}$. This modification of chitosan increased the number of active sites, mainly amine and hydroxyl groups, increasing the coordination with $\mathrm{U}(\mathrm{VI})$ [109].

Including uranium, the biosorption technique has recently been shown to be useful for removing metals from radioactive liquid organic waste. Rice and coffee husks (raw and chemically activated) were examined regarding their capacity to remove $\mathrm{U}($ total $),{ }^{241} \mathrm{Am}$ and ${ }^{137} \mathrm{Cs}$, demonstrating that these materials can be used for the treatment of this waste [110].

\subsection{Copper (II)}

Despite the fact that copper is an essential element, when its concentration is high, it is potentially toxic. This generates the need to develop procedures for its elimination from natural environments. Biosorption proves to be a very useful tool for this purpose. Several biosorbents have recently been evaluated to remove this metal. Biomass from the ornamental herb Thevetia peruviana had a biosorption capacity of $187.51 \mathrm{mg} / \mathrm{g}$, far superior to other biomass or pretreated materials [19]. A new Alcanivorax sp. VBW004, resistant to copper toxicity, isolated from the shallow hydrothermal vent (Azores, Portugal) was evaluated for biosorption of this metal. This live biomass, cultured with $100 \mathrm{mg} / \mathrm{mL}$ of copper, reduced the concentration of this metal by $39.5 \%$ after $48 \mathrm{~h}$. Genetic studies revealed that this strain has copper detoxification genes [111]. This fact shows once again that living biomass with adequate characteristics can be superior to dead biomass.

Immobilization was also recently used for copper biosorption. Alginate-immobilized cells (living biomass) of the bacteria Azotobacter nigricans NEWG-1 was able to remove a percentage of copper of $82.35 \pm 2.81 \%$ after $6 \mathrm{~h}$ and with an initial copper concentration of $200 \mathrm{mg} / \mathrm{L}$ [112]. The biomass of the Aspergillus australensis fungus was also used in immobilized form. In this case, commercial samples of a textile made of $100 \%$ polyester were used as an immobilization matrix, living and dead biomass were compared. In this study, it was observed that an active biosorption process took place, resulting in a higher copper removal compared to a passive process [11]. Another example of an immobilized system is the use of biomass from sugar beet shreds in a fixed-bed column. This process was optimized to remove copper using Box-Behnken experimental design with concentration and $\mathrm{pH}$ of the inlet solution and adsorbent dosage as independent variables [24].

Other biomasses that were also tested to assess copper biosorption were Chlorella pyrenoidosa, reaching $0.48 \mathrm{mmol} / \mathrm{g}$ [41] and Ochrobactrum MT180101: in this strain, there were several mechanisms involved in the biosorption of this metal: surface biosorption, extracellular chelation and bienzyme-mediated biotransformation, which supposes a superior efficiency in the copper biosorption [5]. The commercial biomass of the yeast Saccharomyces cerevisiae Perlage ${ }^{\circledR}$ BB with a maximum biosorption capacity of $4.73 \mathrm{mg} / \mathrm{g}$ [113], dead biomass of Penicillium ochrochloron with an average biosorption capacity of $7.53 \mathrm{mg} / \mathrm{g}$ [114], Sargassum filipendula [42] and alginate-based biosorbent produced from seaweed Sargassum sp. with a maximum biosorption capacity of $1.64 \mathrm{mmol} / \mathrm{g}$ [70] are recent examples of different biomasses that have been evaluated to determine their capacity as copper biosorbents.

\subsection{Other Metals}

Other metals that have recently been studied from the point of view of biosorption are shown in Table 2. 
Table 2. Examples of other metals that have recently been studied for their removal through applications related to biosorption.

\begin{tabular}{|c|c|c|c|}
\hline Metal & Biomass & Remarks & Reference \\
\hline \multirow{3}{*}{ Zinc } & Leaves of Corchorus olitorius & Biosorption capacity of $11.63 \mathrm{mg} / \mathrm{g}$ in $120 \mathrm{~min}$ & [115] \\
\hline & Streptomyces K11 & $\begin{array}{ll}- & \text { Living biomass } \\
- & \text { Maximum biosorption capacity of } 0.75 \mathrm{mmol} / \mathrm{g} \\
\end{array}$ & [65] \\
\hline & Rape straw powders & $\begin{array}{ll}\text { - } & \text { Different parts were evaluated } \\
\text { - } & \text { The maximum biosorption capacity obtained } \\
& \text { reached } 36.74 \mathrm{mg} / \mathrm{g}\end{array}$ & [116] \\
\hline Antimony & $\begin{array}{l}\text { Rhodotorula mucilaginosa } \\
\text { Strain DJHN070401 }\end{array}$ & $\begin{array}{l}\text { - } \quad \text { Living cells } \\
\text { Providing that living cells not only improved the } \\
\text { removal efficiency in the presence of metabolic inhibitors } \\
\text { but also prevented intracellular } \mathrm{Sb} \text { (III) being re-released } \\
\text { into the environment }\end{array}$ & [9] \\
\hline Gold & Lysinibacillus sphaericus CBAM5 & $\begin{array}{ll}\text { - } & \text { Biocomposite materials } \\
\text { - } & \text { Cells immobilized in Polycaprolactone (PCL) } \\
\text { microfibrous mats and alginate microcapsules }\end{array}$ & [28] \\
\hline \multirow{2}{*}{ Arsenic } & Sarcodia suiaeand & $\begin{array}{l}\text { External factors affecting algal metabolism and thus } \\
\text { metal-accumulation mechanisms were studied }\end{array}$ & [67] \\
\hline & Pseudomonas aeruginosa AT-01 Strain & $\begin{array}{l}\text { Remediation efficiency at } 2 \mathrm{~h} \text { of incubation was } 97.92 \% \text { with } \\
\text { an initial As concentration of } 10 \mathrm{mg} / \mathrm{L}\end{array}$ & [117] \\
\hline Manganese & Providencia sp. LLDRA6 & $\begin{array}{ll}\text { - } & \mathrm{Mn}(\mathrm{II}) \text { precipitation on the cell surface } \\
\text { - } & \text { Oxidation of } \mathrm{Mn}(\mathrm{II}) \text { into BioMnOx on the cell surface } \\
\text { - } & \text { Intracellular accumulation }\end{array}$ & [118] \\
\hline Platinum & Escherichia coli & $\begin{array}{l}\text { EC20 protein fused to the E. coli cell surface using an } \\
\text { InaKN-based display } \\
\text { Maximum adsorption capacity of } 239.92 \mathrm{mg} / \mathrm{g}\end{array}$ & [34] \\
\hline \multirow{6}{*}{ Nickel } & Lemon peel & Maximum adsorption capacity of $36.74 \mathrm{mg} / \mathrm{g}$ & [33] \\
\hline & Phanerochaete chrysosporium & $\begin{array}{ll} & \text { Living cells } \\
\text { - } & \text { Maximum biosorption capacity of } 46.50 \mathrm{mg} / \mathrm{g} \\
\end{array}$ & [119] \\
\hline & $\begin{array}{c}\text { Surface-engineered } \\
\text { Saccharomyces cerevisiae EBY100 }\end{array}$ & Biosorption capacity of $2.603 \pm 0.004 \mathrm{~g} / \mathrm{g}$ & [120] \\
\hline & Industrial waste brewery sludge & Biosorption capacity of $7.874 \mathrm{mg} / \mathrm{g}$ & [15] \\
\hline & $\begin{array}{l}\text { Alginate-based biosorbent } \\
\text { produced from Sargassum sp. }\end{array}$ & Maximum biosorption capacity of $1.147 \mathrm{mmol} / \mathrm{g}$ & [70] \\
\hline & Fucus vesiculosus & $\begin{array}{ll}\text { - } & \text { Simultaneous biosorption of } \mathrm{Cd}(\mathrm{II}), \mathrm{Ni}(\mathrm{II}) \text { and } \mathrm{Pb}(\mathrm{II}) \\
\text { - } & \text { Maximum biosorption capacity of } 70.1 \mathrm{mg} / \mathrm{g} \text { for } \mathrm{Ni}(\mathrm{II})\end{array}$ & {$[66]$} \\
\hline Lithium & $\begin{array}{l}\text { Aspergillus versicolor and } \\
\text { Kluyveromyces marxianus }\end{array}$ & $\begin{array}{l}\text { Maximum biosorption capacities of } 347.9 \text { and } 409.2 \mu \mathrm{mol} / \mathrm{g} \text { for } \\
\text { A. versicolor and K. marxianus, respectively }\end{array}$ & [47] \\
\hline Cesium & $\begin{array}{l}\text { Haematococcus pluvialis and } \\
\text { Chlorella vulgaris }\end{array}$ & $\begin{array}{l}\text { Cesium accumulation through the potassium } \\
\text { transport channel }\end{array}$ & [121] \\
\hline Dysprosium & Mangifera indica & $\begin{array}{ll}\text { - } & \text { Raw and surface-modified bark powder } \\
\text { - } & \text { Maximum adsorption capacity of } 55.04 \mathrm{mg} / \mathrm{g}\end{array}$ & [88] \\
\hline Tungstate & Garlic peel & $\begin{array}{l}\text { - } \quad \text { Modified by loading with Fe(III), Ti(IV) and Ce(III) } \\
\text { through a cation exchange process } \\
\text { - } \quad \text { Maximum adsorption capacity of } 91.5 \mathrm{mg} / \mathrm{g} \text { with Fe }\end{array}$ & [20] \\
\hline $\begin{array}{l}\text { Lanthanum } \\
\text { and samarium }\end{array}$ & Botryosphaeria rhodina MAMB-05 & Living and dead biomass & [122] \\
\hline \multirow{2}{*}{ Iron } & Elderberry (Sambucus nigra) pomace & $\begin{array}{ll}\text { - } & \text { Fe (III) } \\
\text { - } & \text { Maximum biosorption capacity of } 33.25 \mathrm{mg} / \mathrm{g}\end{array}$ & [123] \\
\hline & Bacillus subtilis & $\begin{array}{ll}- & \text { Fe(II) } \\
\text { - } & \text { Living cells } \\
\text { - } & \text { Maximum biosorption capacity of } 7.25 \mathrm{mg} / \mathrm{g}\end{array}$ & [124] \\
\hline
\end{tabular}

\section{Biosorption of Organic Compounds}

Today, many organic compounds produce undesired effects in natural ecosystems, and some are considered very toxic to humans. Many of these are part of the so-called persistent organic pollutants (POPs) such as pesticides, insecticides, organochlorines, herbicides and polychlorinated biphenyls (PCBs). Although many of these compounds have been known and used for a long time, some are of recent development, and others have been discovered in the environment due to the progress of analytical techniques: these compounds have been called emerging organic contaminants (EOCs) $[125,126]$. Because these compounds cause serious problems in ecosystems even at low concentrations, it is necessary to develop techniques for their elimination. Physico-chemical techniques are sometimes not effective, they are more expensive and they can also generate additional problems. 
In this context, biosorption is an alternative that avoids these inconveniences and for this reason is being increasingly developed to remove this type of substance. This is demonstrated by the number of studies that have recently been carried out to use biosorption in the elimination of these compounds.

The process is performed in a similar way to metal biosorption and, in general, the factors affecting efficiency are the same, although the response to them shows differences that must be studied in each case. Unlike metals, the complexity of these compounds, in terms of their composition, means that they may have different functional groups capable of presenting very different charge values and with different degrees of ionization depending on the $\mathrm{pH}$ of the solution. For this reason, the optimization of this parameter is of great importance, and the optimization values obtained for compounds with different nature show greater diversity than in the case of metals.

Furthermore, these compounds may have different degrees of hydrophobicity and reactivity, which have an effect on the process. Although hydrophobic compounds are not readily soluble in water, such compounds can interact with the biosorbent particles through hydrobophic interaction or can even cross the cell membranes when using living biomass. Therefore, this type of compounds can also be removed by biosorption.

In relation to temperature, its effect is contradictory, and generally the adsorption effectiveness increases with increasing temperature (endothermic process) [56,127]. However, there are results with some organic compounds whose effect was the opposite, indicating in these cases that the biosorption process was exothermic [128]. Finally, the ionic strength of the solution also modifies the biosorption capacity of organic compounds, although its effect seems to be less relevant than in the case of metals. A high concentration of salts is necessary for a significant decrease in the biosorption of these compounds to occur, although this effect is less studied than in the case of metals.

Some examples of organic compounds that have recently been studied will be reviewed in the following sections.

\subsection{Antibiotics}

Antibiotics are found today in relatively high amounts in ecosystems due to their increasing use. In fact, many studies have been carried out to examine the possibilities of biosorption for the removal of antibiotics. Recently, new articles confirm this use. An example of this is the antibiotic dicloxacillin, biosorption studies with this antibiotic that were performed with Indian almond (Terminalia catappa) leaf biomass. The maximum adsorption capacity was $71.94 \mathrm{mg} / \mathrm{g}$. The optimal $\mathrm{pH}$ for this biosorption was 6.0. For the intermolecular interaction such as hydrogen bonds, van der Waals forces could be the main interaction for the dicloxacillin and the surface properties of this biosorbent [129]. Four sulfonamide antibiotics were also recently investigated. Extracellular polymeric substances (EPS) extracted from Klebsiella sp. J1 were used for this purpose and with efficiencies that reached $142.86 \mathrm{mg} / \mathrm{g}$. In this case, the hydrophobic interaction between EPS and sulfonamides seemed to dominate the adsorption process. There was the maximum proportion of sulfonamides at molecular states when the solution $\mathrm{pH}$ was 4.0-5.0, and the molecular states of sulfonamides were favorable for hydrophobic groups to effectively play a role during adsorption process [130].

Biomass from Dialium guineense seed waste was modified with sodium hydroxide and tested as biosorbent for ciprofloxacin. This biomass, modified in this way, exhibited a maximum uptake capacity of $120.34 \mathrm{mg} / \mathrm{g}$ at $\mathrm{pH}=6.0$, higher than some reported adsorbents for this antibiotic [131]. Another antibiotic that was recently evaluated for its elimination by biosorption was oxytetracycline. This antibiotic was effectively removed using a reed-based-beads biosorbent (an enhanced adsorbent from Tunisian reed). The maximum biosorption capacity obtained was $15.78 \mathrm{mg} / \mathrm{g}$ at $\mathrm{pH}=6.0$. In this experiment, an initial mixture of $165.54 \mu \mathrm{mol} / \mathrm{L}$ of oxytetracycline and $362.16 \mu \mathrm{mol} / \mathrm{L}$ of Cd(II) was used, demonstrating the effectiveness of this material to simultaneously remove two pollutants. The biosorption of $\mathrm{Cd}(\mathrm{II})$ cations took place through electrostatic attraction between them and the biosorbent, and the biosorption of oxytetracycline could take place via $\pi-\pi$ stacking, as well as hydrophobic interactions [52]. 


\subsection{Dyes}

Today, dyes are one of the main pollutants. They are produced in large quantities due to their widespread use, and for this reason, they can be released into natural environments. The release of these types of compounds causes serious problems to natural ecosystems due to their toxicity, carcinogenicity and because they also impart an intense color to the waters (even at very low concentrations) and, in addition, they are considered recalcitrant compounds. Therefore, effective treatments are necessary to remove these compounds from the waters. Biosorption is an excellent alternative to conventional methods. In fact, many papers have been published on the removal of these pollutants by biosorption, and recently, dyes continue to dominate biosorption applications.

The cationic dye methylene blue is one of the most widely used dyes in the industry, and for this reason, there is a wide variety of biosorbents that have been evaluated for the elimination of this dye. In recent years, there are also various examples of these proposals, in which both modified and unmodified biomass are used. Thus, coconut waste, chemically modified with acrylic and polyacrylic acids, has been utilized for the removal of this dye. With these modifications, the maximum sorption capacity reached was $138.88 \mathrm{mg} / \mathrm{g}$ at $\mathrm{pH}=10.0$ using the acrylic acid. The sorption mechanism is mainly based on electrostatic interaction and on Lewis acid-base interaction [30]. Cortaderia selloana flower spikes transformed into nanomagnetic particles reached a maximum removal capacity of this dye of $119.05 \mathrm{mg} / \mathrm{g}$ at $\mathrm{pH}=6.0$ and through electrostatic interactions [132].

However, unmodified biomass methods are still the most widely used to remove methylene blue. Recently, it has been made possible to find many examples of this. Brewer's spent grain has recently been used with a maximum adsorbed amount of methylene blue of $284.75 \mathrm{mg} / \mathrm{g}$ at $\mathrm{pH}=11.0$. A possible adsorption mechanism involves electrostatic interaction, electron donors and electron acceptors, hydrogen bonds and $\pi-\pi$ dispersion [133]. Biomass obtained from weeds (Cyanthilium cinereum and Paspalum maritimum) was also evaluated to eliminate this dye, the maximum absorption capacities obtained were 56.18 and $76.34 \mathrm{mg} / \mathrm{g}$, respectively [134]. Fucus vesiculosus dead biomass was also used to remove this dye, presenting a maximum biosorption capacity of $698.48 \mathrm{mg} / \mathrm{g}$ at $\mathrm{pH}=6.0$ by a physical biosorption mechanism related to a cation exchange process between the dye and biomass functional groups, releasing protons $\left(\mathrm{H}^{+}\right)$to the system [135]. Biomass from Bifurcaria bifurcata was also applied to remove this dye with a maximum biosorption capacity of $2744.5 \mathrm{mg} / \mathrm{g}$ in only $15 \mathrm{~min}$. The best adsorption efficiency was obtained at $\mathrm{pH}=5.6$ due to electrostatic interaction [136]. In these examples, although the biomasses of these macroalgae were clearly higher, it is necessary to consider that the brewer's spent grain is a byproduct of the brewing industry produced in large quantities and with few ecological disposal options; in addition, weeds are abundant and with few applications. This shows that the choice of a certain biosorbent depends on many factors that must be evaluated together. The search for new biosorbents is essential to achieve this objective. An interesting example of this is the application of the biomass from brazilian berry seeds (Eugenia uniflora) to remove this dye in conditions closer to reality using two different simulated effluents with a color removal greater than $70 \%$. This material had a biosorption capacity of $189.6 \mathrm{mg} / \mathrm{g}$ at $\mathrm{pH}=8.0$ and presents $\mathrm{OH}$ groups that can perform hydrogen and electrostatic bonds with methylene blue [56]. Other macroalgae also recently used as biomass were Ulva fasciata that reached a maximum adsorption capacity of $244 \mathrm{mg} / \mathrm{g}$ and Sargassum dentifolium with only $66.6 \mathrm{mg} / \mathrm{g}$. In both cases, it was determined that the biosorption of methylene blue was independent of $\mathrm{pH}$ [12].

Crystal violet is another cationic dye that has recently received attention for biosorption. Powdered seeds of the araticum fruit (Annona crassiflora) were used in the biosorption of this dye with a maximum biosorption capacity of $300.96 \mathrm{mg} / \mathrm{g}$ in $120 \mathrm{~min}$ at $\mathrm{pH}=7.5$. Electrostatic interaction played an important role in the biosorption process of this dye since a $\mathrm{pH}$ higher than the zero charge point of the biosorbent (7.2) causes the surface of this material to be negatively charged due to its deprotonation, which favored an increase in its biosorption capacity because crystal violet is a cationic dye, and therefore, interaction with a negative charge on the surface increases the amount of dye biosorbed [18]. Biomass from Diaporthe schini (new fungus recently discovered) reached a maximum 
biosorption capacity of $642.3 \mathrm{mg} / \mathrm{g}$. This biomass was also evaluated in a simulated effluent with a considerable reduction in the color [137]. Finally, as a more sophisticated option, water dispersible $\mathrm{Fe}_{3} \mathrm{O}_{4} /$ Chitosan/Glutaraldehyde nanocomposites (superparamagnetic) were also tested, in this case with a maximum biosorption capacity of $105.47 \mathrm{mg} / \mathrm{g}$. Electrostatic interaction between the negative charge of the biosorbent surface and the positive charge of the dye would explain why this maximum capacity took place at $\mathrm{pH}$ 11.0. Although the maximum removal capacity was lower than the previous cases, the advantage of this technique is its ease and rapid separation from samples, allowing a reusability up to at least ten cycles [138].

The discarded seed biomass from pepper (Capsicum annuum) was tested to remove Basic red 46 dye. Taguchi DoE methodology was employed to optimize the process reaching a dye removal performance of $92.1 \mathrm{mg} / \mathrm{g}$ at $\mathrm{pH}=8.0$ [139].

Biomass derived from macroalgae was also evaluated to remove the Rhodamine B dye. The macroalgae used were Kappaphycus alvarezii, Gracilaria salicornia and Gracilaria edulis, both in native form and ethanol modified. The maximum biosorption capacity determined as 9.84, 11.03, 8.96, 112.35, 105.26 and $97.08 \mathrm{mg} / \mathrm{g}$ at $\mathrm{pH}=2.0$, respectively. At this low $\mathrm{pH}$, there is an increase in the protonation effect on the surface of these materials resulting in a higher biosorption capacity. The modified biomass was more efficient [140].

Anionic dyes are the other group of dyes that also have a multitude of applications, and for this reason, they are also an environmental problem. These types of dyes have also recently been studied as applications in the field of biosorption. Thus, the removal of tartrazine yellow was evaluated using brewer's spent grain as biomass; the maximum adsorbed amount was $26.18 \mathrm{mg} / \mathrm{g}$ at $\mathrm{pH}=2.0$. This adsorption involves electrostatic attraction, $\pi-\pi$ interaction and multilayer formation of dye [133]. Reactive Blue 19 using dead biomass of the brown marine alga Bifurcaria bifurcata, with a maximum adsorbed amount of $88.7 \mathrm{mg} / \mathrm{g}$ in only $15 \mathrm{~min}$ at $\mathrm{pH}=1.0$. At this very low $\mathrm{pH}$, the concentration of $\mathrm{H}_{3} \mathrm{O}^{+}$ was high enough to allow the protonation of sulfonate groups of this dye, which favors the interaction between the dye and the functional groups of the biomass [136]. Eriochrome black T is another example of an anionic dye recently studied for its elimination by biosorption; in this case, using dead biomass of Fucus vesiculosus and with a maximum biosorption capacity of $24.31 \mathrm{mg} / \mathrm{g}$ at $\mathrm{pH}<4.0$. Van der Waals interaction was the main interaction mechanism between this dye and biomass [135]. Biomass from Ocimum gratissimum leaves was tested for the indigo carmine dye biosorption. This biomass obtained a maximum biosorption capacity of $77.52 \mathrm{mg} / \mathrm{g}$, confirming that this capacity was superior to that of other sorbents used to remove this dye. Since this dye is anionic, the most favorable adsorption occurred at pH 2.0 because the surface of this biosorbent is positively charged [128]. Direct Fast Scarlet 4BS was successfully removed using dead biomass from Enteromorpha prolifera with a maximum sorption capacity of $318.87 \mathrm{mg} / \mathrm{g}$ also at $\mathrm{pH}$ 2.0. The adsorption mechanism involved hydrogen bonding, electrostatic attraction and bonding and hydrophobic and van der Waals interaction [127]. Finally, Reactive Red 120, using immobilized biomass of Pseudomonas guariconensis in a Ca-Ag biocarrier matrix, was efficiently eliminated. In this case, since the biomass was alive, in addition to biosorption, biodegradation occurred. Toxic reactive dye was converted into non-toxic compounds. The immobilized bacterial cells exhibited $87 \%$ uptake of this dye, whereas the non-immobilized bacterial cells exhibited a maximum uptake of $37 \%$ [6].

Anionic dyes are better adsorbed at low $\mathrm{pHs}$ - that is, at $\mathrm{pHs}$ below the zero-charge point of the biosorbent-because under this condition, the surface of the biosorbent acquires positive charge.

\subsection{Other Organic Pollutants}

Other organic pollutants of interest have also been treated using biosorption as the primary removal technique. Table 3 shows some examples of the most recently studied organic pollutants. 
Table 3. Examples of other organic pollutants that have recently been evaluated for their removal using biosorption.

\begin{tabular}{|c|c|c|c|c|}
\hline Pollutant & Biomass & Efficiency & Remarks & Reference \\
\hline Phenol & Luffa cylindrica & $28.9 \mathrm{mg} / \mathrm{g}$ & Hybrid material with $4 \% \mathrm{Zn}^{2+}$ & [38] \\
\hline Sterols & $\begin{array}{l}\text { Aspergillus fumigatus } \\
\text { strain LSD-1 }\end{array}$ & $303.03-909.09 \mathrm{mg} / \mathrm{g}$ & Living and dead biomass & [141] \\
\hline $\begin{array}{l}\text { Propranolol } \\
\text { hydrochloride }\end{array}$ & Sargassum filipendula & $1.94 \mathrm{mmol} / \mathrm{g}$ & $\begin{array}{l}\text { Remaining biomass of } \\
\text { alginate extraction }\end{array}$ & [142] \\
\hline Acetylsalicylic acid & $\begin{array}{l}\text { Biosorption onto } \\
\text { fungal-bacterial biofilm } \\
\text { supported on two types of } \\
\text { activated carbons }\end{array}$ & $292.4 \pm 2.01 \mathrm{mg} / \mathrm{g}$ & $\begin{array}{l}\text { Batch and } \\
\text { fixed-bed experiments }\end{array}$ & [143] \\
\hline Nonylphenol & Microalgae & $\begin{array}{l}74.18-92.12 \% \text { in } 120 \mathrm{~h} \text { with initial } \\
\text { concentration } 1 \mathrm{mg} / \mathrm{L}\end{array}$ & Living biomass & [7] \\
\hline $\begin{array}{l}17 \text { alpha-ethinylestradiol } \\
\text { alone and along } \\
\text { with estrone }\end{array}$ & $\begin{array}{l}\text { Yeast biomass from } \\
\text { ethanol industry }\end{array}$ & $24.50 \pm 0.07$ and $0.80 \pm 0.07 \mathrm{mg} / \mathrm{g}$ & $\begin{array}{l}\text { An associative/competitive } \\
\text { sorption process between } \\
\text { both compounds }\end{array}$ & [40] \\
\hline Salicylic acid & Scenedesmus obliquus & $63 \mathrm{mg} / \mathrm{g}$ & $\begin{array}{ll}\text { - } & \text { Batch experiments } \\
\text { - } & \text { Dead biomass }\end{array}$ & [144] \\
\hline Diuron & Moringa oleifera & $5.76 \mathrm{mg} / \mathrm{g}$ & Fixed-bed column & [25] \\
\hline Ibuprofen & Scenedesmus obliquus & $11.9 \mathrm{mg} / \mathrm{g}$ & $\begin{array}{ll}\text { - } & \text { Batch experiments } \\
\text { - } & \text { Dead biomass }\end{array}$ & [144] \\
\hline Triclosan & Phaeodactylum tricornutum & $12.97-13.03 \mathrm{mg} / \mathrm{g}$ & $\begin{array}{ll}- & \text { Seawater } \\
- & \text { Living and dead biomass } \\
& \text { and photodegradation }\end{array}$ & [10] \\
\hline
\end{tabular}

As can be seen in this table, the nature of the organic compounds is very varied, which is indicative of the enormous possibilities that biosorption techniques have for the removal of this type of pollutant. In addition, these examples reflect the flexibility of biosorption techniques since, in the same way as for other pollutants, biomass can be alive or dead, in batch or in fixed-bed experiments, but it is noteworthy that even this technique can be coupled to an alternating current system that allows increasing the speed of biosorption [38]. However, the removal capacity that some of these sorbents have is far from that achieved with commercial sorbents such as activated carbon. Although the comparison data are scarce, the values obtained indicate the need to search for biomaterials with greater capacity - for example, the biomass of Scenedesmus obliquus had a maximum removal capacity of salicylic acid and ibuprofen of 63 and $11.9 \mathrm{mg} / \mathrm{g}$, respectively; instead in the same conditions, activated carbon had 250 and $147 \mathrm{mg} / \mathrm{g}$ [144].

\section{Conclusions and Future Perspectives}

As can be seen, the field of biosorption continues to offer very promising results for the elimination of pollutants. It is a technology that presents a great diversity of options and combinations, demonstrating great flexibility for its application. It is difficult to limit the studies that try to reveal the properties of any material for use in biosorption. The reason for this is obvious: the amount of possible materials (living or dead) is enormous. These studies must continue to progress because without a material with adequate properties, biosorption cannot be competitive. However, it is not only necessary to determine the properties of a possible material but also to evaluate it compared to others already established as sorbents (commercial sorbents), and therefore, conclude that this new material is a better alternative. There are still steps to be taken for biosorbents to be fully accepted. Currently, there are several challenges of biosorption: the development of large-scale procedures, greater commercialization and, in general, its application in real conditions. Although the advantages of this type of sorbent are evident (mainly cost), few biosorbents are currently marketed for their use [22]. The application of biosorption at the industrial scale has not been yet well exploited, and this constitutes another of the weaknesses that biosorption must face. Still, the vast majority of biosorption applications focus on laboratory studies. All these studies make possible the current knowledge about biosorption that is enough to provide a solid base that allows its use to be extended. However, this process is not widely used in industry. 
An important reason that can explain these weaknesses is that biosorbents, in their natural state, tend to have a lower removal capacity than traditional or conventional sorbents such as activated carbons, zeolites or ion exchange resins. However, it is difficult to ascertain this fact because at present there are still few studies in which a biosorbent is compared with commercial sorbents under the same conditions $[145,146]$. Perhaps, the fact of thinking that a biosorbent may be less effective than the traditional ones could be counterproductive to achieve that biosorbents climb positions, because the true capacity of these materials will remain unknown. The fact that the matrices used in the experiments have different physicochemical properties does not help much in improving the perception of biosorption, since this makes it difficult to compare biosorbents to obtain the one with the highest affinity for a pollutant. A certain standardization could be interesting to solve this aspect.

In any case, if the above is true and biosorbents lack the necessary efficiency, this would imply the need to modify them to achieve greater efficiency. It would be desirable if the biosorbents had, at least, characteristics comparable in efficiency to the commercial ones. There are several alternatives that can improve the effectiveness of biosorbents, ranging from chemical or physical modifications to the use of nanomaterials [29,63,73]. Chemical of physical modifications applies mainly to dead biomass. However, these alternatives would increase the cost of the final product, and the resulting material could be even less eco-friendly, reducing the virtues of biomaterials. In this context, it is interesting not to forget the use of living biomass to improve the effectiveness of a pollutant removal process. Despite the advantages attributed to dead biomass, the properties of living biomass for application as biosorbents have not yet been adequately exploited or even better studied. Many studies indicate that the use of living biomass is more efficient than dead biomass, and living biomass is used without modification. The cost of the production and maintenance of living biomass is among the problems attributed to the use of this type of biomass; however, there are organisms that can be cultivated intensively and with low cost [147]. Macrophytes, microorganisms such as microalgae or some species of bacteria offer very promising results. Studies in this direction should continue.

Immobilization is another key mechanism to improve biosorption processes. It is also a fundamental mechanism for the application of biosorbents on an industrial scale. At present, different proposals are still being evaluated to solve the practical problems of immobilization, especially when living biomass is used [106]. In fact, there has been an increase in the number of studies using immobilized living biomass, perhaps because for many industrial applications, the use of living biomass is preferable. The support for this biomass is being increasingly perfected, as well as the search for the most suitable living biomass for each case, which is essential to ensure that a biosorbent can be successful in its application. An example of this improvement is an alternative that is being exploited by combining nanoparticles with biomass. Microbial cells immobilized on magnetic nanoparticles is a relevant new technique applied to obtain new biosorbents, which has several advantages [29]. However, it is necessary to recognize that the cost of these biocomposite materials can be uncompetitive, as well as an option that can be considered not very eco-friendly. In any case, living biomass immobilization techniques must continue to be refined, seeking more natural and cheaper supports.

Another weakness of biosorption is that many biosorption studies use synthetic wastewater or solutions in distilled water, which does not take into account the behavior of these sorbents with different competitors or with physicochemical parameters that can differ considerably in real conditions. The evaluation of biosorbents in real situations would provide more information and would allow a more adequate assessment of the possibilities of this technique. For this reason, future research should be directed in this direction.

Finally, it is hoped that in the future, as the weaknesses are resolved, biosorption will find its place in industry and in separation technologies.

Funding: This work was carried out with the financial support of the Spanish "Ministerio de Economía, Industria y Competitividad" (CTM2017-88668-R).

Conflicts of Interest: The authors declare no conflict of interest. 


\section{References}

1. Santaeufemia, S.; Torres, E.; Mera, R.; Abalde, J. Bioremediation of oxytetracycline in seawater by living and dead biomass of the microalga Phaeodactylum tricornutum. J. Hazard. Mater. 2016, 320, 315-325. [CrossRef] [PubMed]

2. Yu, R.; Chai, H.; Yu, Z.; Wu, X.; Liu, Y.; Shen, L.; Li, J.; Ye, J.; Liu, D.; Ma, T.; et al. Behavior and Mechanism of Cesium Biosorption from Aqueous Solution by Living Synechococcus PCC7002. Microorganisms 2020, 8, 491. [CrossRef] [PubMed]

3. Wang, X.; Li, D.; Gao, P.; Gu, W.; He, X.; Yang, W.; Tang, W. Analysis of biosorption and biotransformation mechanism of Pseudomonas chengduensis strain MBR under Cd(II) stress from genomic perspective. Ecotoxicol. Environ. Saf. 2020, 198, 110655. [CrossRef] [PubMed]

4. Rogowska, A.; Pomastowski, P.; Rafinska, K.; Railean-Plugaru, V.; Zloch, M.; Walczak, J.; Buszewski, B. A study of zearalenone biosorption and metabolisation by prokaryotic and eukaryotic cells. Toxicon 2019, 169, 81-90. [CrossRef] [PubMed]

5. Peng, H.; Li, D.; Ye, J.; Xu, H.; Xie, W.; Zhang, Y.; Wu, M.; Xu, L.; Liang, Y.; Liu, W. Biosorption behavior of the Ochrobactrum MT180101 on ionic copper and chelate copper. J. Environ. Manag. 2019, 235, $224-230$. [CrossRef] [PubMed]

6. Reddy, S.; Osborne, J.W. Biodegradation and biosorption of Reactive Red 120 dye by immobilized Pseudomonas guariconensis: Kinetic and toxicity study. Water Environ. Res. 2020. [CrossRef]

7. Wang, L.; Xiao, H.; He, N.; Sun, D.; Duan, S. Biosorption and Biodegradation of the Environmental Hormone Nonylphenol by Four Marine Microalgae. Sci. Rep. 2019, 9, 5277. [CrossRef]

8. Xu, S.; Xing, Y.; Liu, S.; Hao, X.; Chen, W.; Huang, Q. Characterization of Cd(2+) biosorption by Pseudomonas sp. strain 375 , a novel biosorbent isolated from soil polluted with heavy metals in Southern China. Chemosphere 2020, 240, 124893. [CrossRef]

9. Jin, C.S.; Deng, R.J.; Ren, B.Z.; Hou, B.L.; Hursthouse, A.S. Enhanced Biosorption of Sb(III) onto Living Rhodotorula mucilaginosa Strain DJHN070401: Optimization and Mechanism. Curr. Microbiol. 2020, 77, 2071-2083. [CrossRef]

10. Santaeufemia, S.; Abalde, J.; Torres, E. Eco-friendly rapid removal of triclosan from seawater using biomass of a microalgal species: Kinetic and equilibrium studies. J. Hazard. Mater. 2019, 369, 674-683. [CrossRef]

11. Contreras-Cortes, A.G.; Almendariz-Tapia, F.J.; Cortez-Rocha, M.O.; Burgos-Hernandez, A.; Rosas-Burgos, E.C.; Rodriguez-Felix, F.; Gomez-Alvarez, A.; Quevedo-Lopez, M.A.; Plascencia-Jatomea, M. Biosorption of copper by immobilized biomass of Aspergillus australensis. Effect of metal on the viability, cellular components, polyhydroxyalkanoates production, and oxidative stress. Environ. Sci. Pollut. Res. Int. 2020, 27, 28545-28560. [CrossRef]

12. Moghazy, R.M.; Labena, A.; Husien, S. Eco-friendly complementary biosorption process of methylene blue using micro-sized dried biosorbents of two macro-algal species (Ulva fasciata and Sargassum dentifolium): Full factorial design, equilibrium, and kinetic studies. Int. J. Biol. Macromol. 2019, 134, 330-343. [CrossRef]

13. Jaafari, J.; Yaghmaeian, K. Optimization of heavy metal biosorption onto freshwater algae (Chlorella coloniales) using response surface methodology (RSM). Chemosphere 2019, 217, 447-455. [CrossRef] [PubMed]

14. Carvalho Costa, A.W.M.; Guerhardt, F.; Ribeiro Junior, S.E.R.; Canovas, G.; Vanale, R.M.; de Freitas Coelho, D.; Ehrhardt, D.D.; Rosa, J.M.; BasileTambourgi, E.; Curvelo Santana, J.C.; et al. Biosorption of Cr(VI) using coconut fibers from agro-industrial waste magnetized using magnetite nanoparticles. Environ. Technol. 2020, 1-12. [CrossRef] [PubMed]

15. Kulkarni, R.M.; Vidya Shetty, K.; Srinikethan, G. Kinetic and equilibrium modeling of biosorption of nickel (II) and cadmium (II) on brewery sludge. Water Sci. Technol. 2019, 79, 888-894. [CrossRef] [PubMed]

16. Taki, K.; Gogoi, A.; Mazumder, P.; Bhattacharya, S.S.; Kumar, M. Efficacy of vermitechnology integration with Upflow Anaerobic Sludge Blanket (UASB) and activated sludge for metal stabilization: A compliance study on fractionation and biosorption. J. Environ. Manag. 2019, 236, 603-612. [CrossRef]

17. Hussein, M.H.; Hamouda, R.A.; Elhadary, A.M.A.; Abuelmagd, M.A.; Ali, S.; Rizwan, M. Characterization and chromium biosorption potential of extruded polymeric substances from Synechococcus mundulus induced by acute dose of gamma irradiation. Environ. Sci Pollut. Res. Int. 2019, 26, 31998-32012. [CrossRef] 
18. Franco, D.S.P.; Georgin, J.; Drumm, F.C.; Netto, M.S.; Allasia, D.; Oliveira, M.L.S.; Dotto, G.L. Araticum (Annona crassiflora) seed powder (ASP) for the treatment of colored effluents by biosorption. Environ. Sci. Pollut. Res. Int. 2020, 27, 11184-11194. [CrossRef]

19. Medhi, H.; Chowdhury, P.R.; Baruah, P.D.; Bhattacharyya, K.G. Kinetics of Aqueous Cu(II) Biosorption onto Thevetia peruviana Leaf Powder. ACS Omega 2020, 5, 13489-13502. [CrossRef]

20. Wang, Y.; Huang, K. Biosorption of tungstate onto garlic peel loaded with Fe(III), Ce(III), and Ti(IV). Environ. Sci. Pollut. Res. Int. 2020, 27, 33692-33702. [CrossRef]

21. Zhang, J.; Wang, P.; Zhang, Z.; Xiang, P.; Xia, S. Biosorption Characteristics of Hg(II) from Aqueous Solution by the Biopolymer from Waste Activated Sludge. Int. J. Environ. Res. Public Health 2020, 17, 1488. [CrossRef]

22. de Freitas, G.R.; da Silva, M.G.C.; Vieira, M.G.A. Biosorption technology for removal of toxic metals: A review of commercial biosorbents and patents. Environ. Sci. Pollut. Res. Int. 2019, 26, 19097-19118. [CrossRef]

23. Fomina, M.; Gadd, G.M. Biosorption: Current perspectives on concept, definition and application. Bioresour. Technol. 2014, 160, 3-14. [CrossRef]

24. Blagojev, N.; Kukic, D.; Vasic, V.; Sciban, M.; Prodanovic, J.; Bera, O. A new approach for modelling and optimization of $\mathrm{Cu}(\mathrm{II})$ biosorption from aqueous solutions using sugar beet shreds in a fixed-bed column. J. Hazard. Mater. 2019, 363, 366-375. [CrossRef]

25. Wernke, G.; Fagundes-Klen, M.R.; Vieira, M.F.; Suzaki, P.Y.R.; Souza, H.K.S.; Shimabuku, Q.L.; Bergamasco, R. Mathematical modelling applied to the rate-limiting mass transfer step determination of a herbicide biosorption onto fixed-bed columns. Environ. Technol. 2020, 41, 638-648. [CrossRef]

26. Aryal, M. Calcium alginate entrapped Eupatorium adenophorum Sprengel stems powder for chromium(VI) biosorption in aqueous mediums. PLoS ONE 2019, 14, e0213477. [CrossRef]

27. Ahmad, A.; Bhat, A.H.; Buang, A. Enhanced biosorption of transition metals by living Chlorella vulgaris immobilized in Ca-alginate beads. Environ. Technol. 2019, 40, 1793-1809. [CrossRef]

28. Paez-Velez, C.; Castro-Mayorga, J.L.; Dussan, J. Effective Gold Biosorption by Electrospun and Electrosprayed Bio-composites with Immobilized Lysinibacillus sphaericus CBAM5. Nanomaterials (Basel) 2020, 10, 408. [CrossRef]

29. Giese, E.C.; Silva, D.D.V.; Costa, A.F.M.; Almeida, S.G.C.; Dussan, K.J. Immobilized microbial nanoparticles for biosorption. Crit. Rev. Biotechnol. 2020, 40, 653-666. [CrossRef]

30. Kocaman, S. Synthesis and cationic dye biosorption properties of a novel low-cost adsorbent: Coconut waste modified with acrylic and polyacrylic acids. Int. J. Phytoremediat. 2020, 22, 551-566. [CrossRef]

31. Zhang, J.; Chen, X.; Zhou, J.; Luo, X. Uranium biosorption mechanism model of protonated Saccharomyces cerevisiae. J. Hazard. Mater. 2020, 385, 121588. [CrossRef] [PubMed]

32. Ribeiro, V.R.; Maciel, G.M.; Fachi, M.M.; Pontarolo, R.; Fernandes, I.A.A.; Stafussa, A.P.; Haminiuk, C.W.I. Improvement of phenolic compound bioaccessibility from yerba mate (Ilex paraguariensis) extracts after biosorption on Saccharomyces cerevisiae. Food Res. Int. 2019, 126, 108623. [CrossRef] [PubMed]

33. Villen-Guzman, M.; Gutierrez-Pinilla, D.; Gomez-Lahoz, C.; Vereda-Alonso, C.; Rodriguez-Maroto, J.M.; Arhoun, B. Optimization of $\mathrm{Ni}$ (II) biosorption from aqueous solution on modified lemon peel. Environ. Res. 2019, 179, 108849. [CrossRef]

34. Tan, L.; Cui, H.; Xiao, Y.; Xu, H.; Xu, M.; Wu, H.; Dong, H.; Qiu, G.; Liu, X.; Xie, J. Enhancement of platinum biosorption by surface-displaying EC20 on Escherichia coli. Ecotoxicol. Environ. Saf. 2019, 169, 103-111. [CrossRef]

35. Dong, X.B.; Huang, W.; Bian, Y.B.; Feng, X.; Ibrahim, S.A.; Shi, D.F.; Qiao, X.; Liu, Y. Remediation and Mechanisms of Cadmium Biosorption by a Cadmium-Binding Protein from Lentinula edodes. J. Agric. Food Chem. 2019, 67, 11373-11379. [CrossRef]

36. De Oliveira, V.H.; Ullah, I.; Dunwell, J.M.; Tibbett, M. Bioremediation potential of Cd by transgenic yeast expressing a metallothionein gene from Populus trichocarpa. Ecotoxicol. Environ. Saf. 2020, 202, 110917. [CrossRef]

37. Othmani, A.; Kesraoui, A.; HaneneAkrout; Elaissaoui, I.; Seffen, M. Coupling anodic oxidation, biosorption and alternating current as alternative for wastewater purification. Chemosphere 2020, 249, 126480. [CrossRef]

38. Othmani, A.; Kesraoui, A.; Seffen, M. Removal of phenol from aqueous solution by coupling alternating current with biosorption. Environ. Sci. Pollut. Res. Int. 2020. [CrossRef] 
39. de Freitas, G.R.; Vieira, M.G.A.; da Silva, M.G.C. Fixed bed biosorption of silver and investigation of functional groups on acidified biosorbent from algae biomass. Environ. Sci. Pollut. Res. Int. 2019, 26, 36354-36366. [CrossRef]

40. Debs, K.B.; da Silva, H.D.T.; de Moraes, M.D.L.L.; Carrilho, E.; Lemos, S.G.; Labuto, G. Biosorption of 17alpha-ethinylestradiol by yeast biomass from ethanol industry in the presence of estrone. Environ. Sci. Pollut. Res. Int. 2019, 26, 28419-28428. [CrossRef]

41. Chen, X.; Zheng, M.; Zhang, G.; Li, F.; Chen, H.; Leng, Y. The nature of dissolved organic matter determines the biosorption capacity of $\mathrm{Cu}$ by algae. Chemosphere 2020, 252, 126465. [CrossRef]

42. do Nascimento Junior, W.J.; da Silva, M.G.C.; Vieira, M.G.A. Competitive biosorption of $\mathrm{Cu}\left({ }^{2+}\right)$ and $\mathrm{Ag}\left({ }^{+}\right)$ ions on brown macro-algae waste: Kinetic and ion-exchange studies. Environ. Sci. Pollut. Res. Int. 2019, 26, 23416-23428. [CrossRef]

43. Costa, C.S.D.; Queiroz, B.G.M.; Landers, R.; da Silva, M.G.C.; Vieira, M.G.A. Equilibrium study of binary mixture biosorption of $\mathrm{Cr}(\mathrm{III})$ and $\mathrm{Zn}(\mathrm{II})$ by dealginated seaweed waste: Investigation of adsorption mechanisms using X-ray photoelectron spectroscopy analysis. Environ. Sci. Pollut. Res. Int. 2019, 26, 28470-28480. [CrossRef]

44. Rahman, Z.; Thomas, L.; Singh, V.P. Biosorption of heavy metals by a lead $(\mathrm{Pb})$ resistant bacterium, Staphylococcus hominis strain AMB-2. J. Basic Microbiol. 2019, 59, 477-486. [CrossRef]

45. Liu, L.; Liu, J.; Liu, X.; Dai, C.; Zhang, Z.; Song, W.; Chu, Y. Kinetic and equilibrium of U(VI) biosorption onto the resistant bacterium Bacillus amyloliquefaciens. J. Environ. Radioact. 2019, 203, 117-124. [CrossRef]

46. Wang, N.; Qiu, Y.; Xiao, T.; Wang, J.; Chen, Y.; Xu, X.; Kang, Z.; Fan, L.; Yu, H. Comparative studies on Pb(II) biosorption with three spongy microbe-based biosorbents: High performance, selectivity and application. J. Hazard. Mater. 2019, 373, 39-49. [CrossRef]

47. Gunan Yucel, H.; Aksu, Z.; Yalcinkaya, G.B.; Karatay, S.E.; Donmez, G. A comparative investigation of lithium(I) biosorption properties of Aspergillus versicolor and Kluyveromyces marxianus. Water Sci. Technol. 2020, 81, 499-507. [CrossRef]

48. Adekanmbi, E.O.; Giduthuri, A.T.; Carv, B.A.C.; Counts, J.; Moberly, J.G.; Srivastava, S.K. Application of dielectrophoresis towards characterization of rare earth elements biosorption by Cupriavidus necator. Anal. Chim. Acta 2020, 1129, 150-157. [CrossRef]

49. Lagergren, S. About the theory of so-Called adsorption of soluble substance. Handlingar 1898, 24, 1-39.

50. Blanchard, G.; Maunaye, M.; Martin, G. Removal of heavy metals from waters by means of natural zeolites. Water Res. 1984, 18, 1501-1507. [CrossRef]

51. Weber, W.J.; Morris, J.C. Kinetics of adsorption on carbon from solutions. J. Sanit. Eng. Div. 1963, 89, 31-60.

52. Karoui, S.; Ben Arfi, R.; Fernandez-Sanjurjo, M.J.; Nunez-Delgado, A.; Ghorbal, A.; Alvarez-Rodriguez, E. Optimization of synergistic biosorption of oxytetracycline and cadmium from binary mixtures on reed-based beads: Modeling study using Brouers-Sotolongo models. Environ. Sci. Pollut. Res. Int. 2020. [CrossRef]

53. Langmuir, I. The adsorption of gases on plane surfaces of glass, mica and platinum. J. Am. Chem. Soc. 1918, 40, 1361-1403. [CrossRef]

54. Freundlich, H.M.F. Over the adsorption in solution. J. Phys. Chem. 1906, 57, 385-470.

55. Giese, E.C. Biosorption as green technology for the recovery and separation of rare earth elements. World J. Microbiol. Biotechnol. 2020, 36, 52. [CrossRef]

56. Georgin, J.; Franco, D.S.P.; Netto, M.S.; Allasia, D.; Oliveira, M.L.S.; Dotto, G.L. Treatment of water containing methylene by biosorption using Brazilian berry seeds (Eugenia uniflora). Environ. Sci. Pollut. Res. Int. 2020, 27, 20831-20843. [CrossRef]

57. Ribeiro, C.; Scheufele, F.B.; Alves, H.J.; Kroumov, A.D.; Espinoza-Quinones, F.R.; Modenes, A.N.; Borba, C.E. Evaluation of hybrid neutralization/biosorption process for zinc ions removal from automotive battery effluent by dolomite and fish scales. Environ. Technol. 2019, 40, 2373-2388. [CrossRef]

58. Volesky, B. Biosorption of Heavy Metals; Volesky, B., Ed.; CRC Press: Boca Raton, FL, USA, 1990; p. 396.

59. Tsezos, M.; Volesky, B. The mechanism of thorium biosorption by Rhizopus arrhizus. Biotechnol. Bioeng. 1982, 24, 955-969. [CrossRef]

60. Fisher, R.M.; Gupta, V. Heavy Metals; StatPearls Publishing: Treasure Island, FL, USA, 2020.

61. Jaishankar, M.; Tseten, T.; Anbalagan, N.; Mathew, B.B.; Beeregowda, K.N. Toxicity, mechanism and health effects of some heavy metals. Interdiscip. Toxicol. 2014, 7, 60-72. [CrossRef] 
62. Tchounwou, P.B.; Yedjou, C.G.; Patlolla, A.K.; Sutton, D.J. Heavy metal toxicity and the environment. Exp. Suppl. 2012, 101, 133-164. [CrossRef]

63. Qin, H.; Hu, T.; Zhai, Y.; Lu, N.; Aliyeva, J. The improved methods of heavy metals removal by biosorbents: A review. Environ. Pollut. 2020, 258, 113777. [CrossRef] [PubMed]

64. Dinh, V.P.; Xuan, T.D.; Hung, N.Q.; Luu, T.T.; Do, T.T.; Nguyen, T.D.; Nguyen, V.D.; Anh, T.T.K.; Tran, N.Q. Primary biosorption mechanism of lead (II) and cadmium (II) cations from aqueous solution by pomelo (Citrus maxima) fruit peels. Environ. Sci. Pollut. Res. Int. 2020. [CrossRef] [PubMed]

65. Sedlakova-Kadukova, J.; Kopcakova, A.; Gresakova, L.; Godany, A.; Pristas, P. Bioaccumulation and biosorption of zinc by a novel Streptomyces K11 strain isolated from highly alkaline aluminium brown mud disposal site. Ecotoxicol. Environ. Saf. 2019, 167, 204-211. [CrossRef] [PubMed]

66. Moreira, V.R.; Lebron, Y.A.R.; Lange, L.C.; Santos, L.V.S. Simultaneous biosorption of Cd(II), Ni(II) and $\mathrm{Pb}$ (II) onto a brown macroalgae Fucus vesiculosus: Mono- and multi-component isotherms, kinetics and thermodynamics. J. Environ. Manag. 2019, 251, 109587. [CrossRef]

67. Libatique, M.J.H.; Lee, M.C.; Yeh, H.Y.; Jhang, F.J. Total and inorganic arsenic biosorption by Sarcodia suiae (Rhodophyta), as affected by controlled environmental conditions. Chemosphere 2020, 248, 126084. [CrossRef]

68. Hu, X.; Cao, J.; Yang, H.; Li, D.; Qiao, Y.; Zhao, J.; Zhang, Z.; Huang, L. Pb ${ }^{2+}$ biosorption from aqueous solutions by live and dead biosorbents of the hydrocarbon-degrading strain Rhodococcus sp. HX-2. PLoS ONE 2020, 15, e0226557. [CrossRef]

69. Dai, Q.H.; Bian, X.Y.; Li, R.; Jiang, C.B.; Ge, J.M.; Li, B.L.; Ou, J. Biosorption of lead(II) from aqueous solution by lactic acid bacteria. Water Sci. Technol. 2019, 79, 627-634. [CrossRef]

70. Barquilha, C.E.R.; Cossich, E.S.; Tavares, C.R.G.; da Silva, E.A. Biosorption of nickel(II) and copper(II) ions from synthetic and real effluents by alginate-based biosorbent produced from seaweed Sargassum sp. Environ. Sci. Pollut. Res. Int. 2019, 26, 11100-11112. [CrossRef]

71. Lin, Z.; Li, J.; Luan, Y.; Dai, W. Application of algae for heavy metal adsorption: A 20-year meta-analysis. Ecotoxicol. Environ. Saf. 2020, 190, 110089. [CrossRef]

72. Ojima, Y.; Kosako, S.; Kihara, M.; Miyoshi, N.; Igarashi, K.; Azuma, M. Recovering metals from aqueous solutions by biosorption onto phosphorylated dry baker's yeast. Sci. Rep. 2019, 9, 225. [CrossRef]

73. Zoroufchi, B.K.; Motalebi, D.A.; McPhedran, K.N.; Soltan, J. Treatment of aqueous arsenic-A review of biosorbent preparation methods. J. Environ. Manag. 2020, 273, 111126. [CrossRef] [PubMed]

74. Zhang, C.; Ren, H.X.; Zhong, C.Q.; Wu, D. Biosorption of Cr(VI) by immobilized waste biomass from polyglutamic acid production. Sci. Rep. 2020, 10, 3705. [CrossRef] [PubMed]

75. Rambabu, K.; Bharath, G.; Banat, F.; Show, P.L. Biosorption performance of date palm empty fruit bunch wastes for toxic hexavalent chromium removal. Environ. Res. 2020, 187, 109694. [CrossRef] [PubMed]

76. Kumar, S.; Shahnaz, T.; Selvaraju, N.; Rajaraman, P.V. Kinetic and thermodynamic studies on biosorption of $\mathrm{Cr}(\mathrm{VI})$ on raw and chemically modified Datura stramonium fruit. Environ. Monit. Assess. 2020, 192, 248. [CrossRef] [PubMed]

77. Kalola, V.; Desai, C. Biosorption of Cr(VI) by Halomonas sp. DK4, a halotolerant bacterium isolated from chrome electroplating sludge. Environ. Sci. Pollut. Res. Int. 2020, 27, 27330-27344. [CrossRef] [PubMed]

78. Mishra, A.; Gupta, B.; Kumar, N.; Singh, R.; Varma, A.; Thakur, I.S. Synthesis of calcite-based bio-composite biochar for enhanced biosorption and detoxification of chromium $\mathrm{Cr}$ (VI) by Zhihengliuella sp. ISTPL4. Bioresour. Technol. 2020, 307, 123262. [CrossRef]

79. Aranda-Garcia, E.; Cristiani-Urbina, E. Hexavalent chromium removal and total chromium biosorption from aqueous solution by Quercus crassipes acorn shell in a continuous up-flow fixed-bed column: Influencing parameters, kinetics, and mechanism. PLoS ONE 2020, 15, e227953. [CrossRef]

80. Antony, G.S.; Manna, A.; Baskaran, S.; Puhazhendi, P.; Ramchary, A.; Niraikulam, A.; Ramudu, K.N. Non-enzymatic reduction of $\mathrm{Cr}(\mathrm{VI})$ and it's effective biosorption using heat-inactivated biomass: A fermentation waste material. J. Hazard. Mater. 2020, 392, 122257. [CrossRef]

81. Wang, J.; Xie, Q.; Li, A.; Liu, X.; Yu, F.; Ji, J. Biosorption of hexavalent chromium from aqueous solution by polyethyleneimine-modified ultrasonic-assisted acid hydrochar from Sargassum horneri. Water Sci. Technol. 2020, 81, 1114-1129. [CrossRef]

82. Prabhu, S.G.; Srinikethan, G.; Hegde, S. Spontaneous Cr(VI) and Cd(II) biosorption potential of native pinnae tissue of Pteris vittata L., a tropical invasive pteridophyte. Int. J. Phytoremediat. 2019, 21, 380-390. [CrossRef] 
83. Gocenoglu, A. Kinetic and thermodynamic studies of the biosorption of $\mathrm{Cr}$ (VI) in aqueous solutions by Agaricus campestris. Environ. Technol. 2019, 1-9. [CrossRef]

84. da Rocha Ferreira, G.L.; Vendruscolo, F.; Antoniosi Filho, N.R. Biosorption of hexavalent chromium by Pleurotus ostreatus. Heliyon 2019, 5, e01450. [CrossRef]

85. Chang, J.; Deng, S.; Liang, Y.; Chen, J. Cr(VI) removal performance from aqueous solution by Pseudomonas sp. strain DC-B3 isolated from mine soil: Characterization of both $\mathrm{Cr}(\mathrm{VI})$ bioreduction and total Cr biosorption processes. Environ. Sci. Pollut. Res. Int. 2019, 26, 28135-28145. [CrossRef]

86. Campana-Perez, J.F.; Portero Barahona, P.; Martin-Ramos, P.; Carvajal Barriga, E.J. Ecuadorian yeast species as microbial particles for Cr(VI) biosorption. Environ. Sci. Pollut. Res. Int. 2019, 26, 28162-28172. [CrossRef]

87. Tyagi, B.; Gupta, B.; Thakur, I.S. Biosorption of Cr (VI) from aqueous solution by extracellular polymeric substances (EPS) produced by Parapedobacter sp. ISTM3 strain isolated from Mawsmai cave, Meghalaya, India. Environ. Res. 2020, 191, 110064. [CrossRef]

88. Devi, A.P.; Mishra, P.M. Biosorption of dysprosium (III) using raw and surface-modified bark powder of Mangifera indica: Isotherm, kinetic and thermodynamic studies. Environ. Sci. Pollut. Res. Int. 2019, 26, 6545-6556. [CrossRef]

89. Wang, L.; Li, Z.; Wang, Y.; Brookes, P.C.; Wang, F.; Zhang, Q.; Xu, J.; Liu, X. Performance and mechanisms for remediation of $\mathrm{Cd}(\mathrm{II})$ and $\mathrm{As}(\mathrm{III})$ co-contamination by magnetic biochar-microbe biochemical composite: Competition and synergy effects. Sci. Total Environ. 2020, 750, 141672. [CrossRef]

90. Huang, H.; Jia, Q.; Jing, W.; Dahms, H.U.; Wang, L. Screening strains for microbial biosorption technology of cadmium. Chemosphere 2020, 251, 126428. [CrossRef]

91. Wang, Q.; Li, Q.; Lin, Y.; Hou, Y.; Deng, Z.; Liu, W.; Wang, H.; Xia, Z. Biochemical and genetic basis of cadmium biosorption by Enterobacter ludwigii LY6, isolated from industrial contaminated soil. Environ. Pollut. 2020, 264, 114637. [CrossRef]

92. Boczonadi, I.; Torok, Z.; Jakab, A.; Konya, G.; Gyurcso, K.; Baranyai, E.; Szoboszlai, Z.; Donczo, B.; Fabian, I.; Leiter, E.; et al. Increased $\mathrm{Cd}\left({ }^{2+}\right)$ biosorption capability of Aspergillus nidulans elicited by crpA deletion. J. Basic Microbiol. 2020, 60, 574-584. [CrossRef]

93. Ibuot, A.; Webster, R.E.; Williams, L.E.; Pittman, J.K. Increased metal tolerance and bioaccumulation of zinc and cadmium in Chlamydomonas reinhardtii expressing a AtHMA4 C-terminal domain protein. Biotechnol. Bioeng. 2020. [CrossRef]

94. Jin, Z.; Xie, L.; Zhang, T.; Liu, L.; Black, T.; Jones, K.C.; Zhang, H.; Wang, X.; Jin, N.; Zhang, D. Interrogating cadmium and lead biosorption mechanisms by Simplicillium chinense via infrared spectroscopy. Environ. Pollut. 2020, 263, 114419. [CrossRef]

95. Yuan, W.; Cheng, J.; Huang, H.; Xiong, S.; Gao, J.; Zhang, J.; Feng, S. Optimization of cadmium biosorption by Shewanella putrefaciens using a Box-Behnken design. Ecotoxicol. Environ. Saf. 2019, 175, 138-147. [CrossRef]

96. Sun, H.; Wang, X.; Wang, R.; Zhang, Y.; Wang, X. Biosorption of $\mathrm{Cd}\left({ }^{2+}\right)$ from aqueous solution by Ca $\left({ }^{2+}\right) / \mathrm{Mg}\left({ }^{2+}\right)$ type Citrus paradisi Macf. peel biosorbents. Water Sci. Technol. 2019, 80, 1205-1212. [CrossRef] [PubMed]

97. Le, B.; Yang, S.H. Biosorption of cadmium by potential probiotic Pediococcus pentosaceus using in vitro digestion model. Biotechnol. Appl. Biochem. 2019, 66, 673-680. [CrossRef]

98. Lu, N.; Hu, T.; Zhai, Y.; Qin, H.; Aliyeva, J.; Zhang, H. Fungal cell with artificial metal container for heavy metals biosorption: Equilibrium, kinetics study and mechanisms analysis. Environ. Res. 2020, 182, 109061. [CrossRef]

99. Mohapatra, R.K.; Parhi, P.K.; Pandey, S.; Bindhani, B.K.; Thatoi, H.; Panda, C.R. Active and passive biosorption of $\mathrm{Pb}(\mathrm{II})$ using live and dead biomass of marine bacterium Bacillus xiamenensis PbRPSD202: Kinetics and isotherm studies. J. Environ. Manag. 2019, 247, 121-134. [CrossRef]

100. Qiao, W.; Zhang, Y.; Xia, H.; Luo, Y.; Liu, S.; Wang, S.; Wang, W. Bioimmobilization of lead by Bacillus subtilis X3 biomass isolated from lead mine soil under promotion of multiple adsorption mechanisms. R. Soc. Open Sci. 2019, 6, 181701. [CrossRef]

101. Jin, Z.; Deng, S.; Wen, Y.; Jin, Y.; Pan, L.; Zhang, Y.; Black, T.; Jones, K.C.; Zhang, H.; Zhang, D. Application of Simplicillium chinense for $\mathrm{Cd}$ and $\mathrm{Pb}$ biosorption and enhancing heavy metal phytoremediation of soils. Sci. Total Environ. 2019, 697, 134148. [CrossRef]

102. Imran, M.; Anwar, K.; Akram, M.; Shah, G.M.; Ahmad, I.; Samad Shah, N.; Khan, Z.U.H.; Rashid, M.I.; Akhtar, M.N.; Ahmad, S.; et al. Biosorption of $\mathrm{Pb}(\mathrm{II})$ from contaminated water onto Moringa oleifera biomass: Kinetics and equilibrium studies. Int. J. Phytoremediat. 2019, 21, 777-789. [CrossRef] 
103. Akram, M.; Khan, B.; Imran, M.; Ahmad, I.; Ajaz, H.; Tahir, M.; Rabbani, F.; Kaleem, I.; Nadeem Akhtar, M.; Ahmad, N.; et al. Biosorption of lead by cotton shells powder: Characterization and equilibrium modeling study. Int. J. Phytoremediat. 2019, 21, 138-144. [CrossRef] [PubMed]

104. Kumar, M.; Singh, A.K.; Sikandar, M. Biosorption of Hg (II) from aqueous solution using algal biomass: Kinetics and isotherm studies. Heliyon 2020, 6, e03321. [CrossRef]

105. Fathollahi, A.; Coupe, S.J.; El-Sheikh, A.H.; Sanudo-Fontaneda, L.A. The biosorption of mercury by permeable pavement biofilms in stormwater attenuation. Sci. Total Environ. 2020, 741, 140411. [CrossRef]

106. Chen, C.; Hu, J.; Wang, J. Biosorption of uranium by immobilized Saccharomyces cerevisiae. J. Environ. Radioact. 2020, 213, 106158. [CrossRef]

107. Vieira, L.C.; de Araujo, L.G.; de Padua Ferreira, R.V.; da Silva, E.A.; Canevesi, R.L.S.; Marumo, J.T. Uranium biosorption by Lemna sp. and Pistia stratiotes. J. Environ. Radioact. 2019, 203, 179-186. [CrossRef]

108. Han, J.; Hu, L.; He, L.; Ji, K.; Liu, Y.; Chen, C.; Luo, X.; Tan, N. Preparation and uranium (VI) biosorption for tri-amidoxime modified marine fungus material. Environ. Sci. Pollut. Res. Int. 2020. [CrossRef]

109. Dai, Y.; Zhou, L.; Tang, X.; Xi, J.; Ouyang, J.; Liu, Z.; Huang, G.; Adesina, A.A. Macroporous ion-imprinted chitosan foams for the selective biosorption of $\mathrm{U}(\mathrm{VI})$ from aqueous solution. Int. J. Biol. Macromol. 2020, 164, 4155-4164. [CrossRef]

110. Ferreira, R.V.P.; de Araujo, L.G.; Canevesi, R.L.S.; da Silva, E.A.; Ferreira, E.G.A.; Palmieri, M.C.; Marumo, J.T. The use of rice and coffee husks for biosorption of $U$ (total), (241)Am, and (137)Cs in radioactive liquid organic waste. Environ. Sci. Pollut. Res. Int. 2020, 27, 36651-36663. [CrossRef]

111. Ramasamy, K.P.; Rajasabapathy, R.; Lips, I.; Mohandass, C.; James, R.A. Genomic features and copper biosorption potential of a new Alcanivorax sp. VBW004 isolated from the shallow hydrothermal vent (Azores, Portugal). Genomics 2020, 112, 3268-3273. [CrossRef]

112. Ghoniem, A.A.; El-Naggar, N.E.; Saber, W.I.A.; El-Hersh, M.S.; El-Khateeb, A.Y. Statistical modeling-approach for optimization of $\mathrm{Cu}(2+)$ biosorption by Azotobacter nigricans NEWG-1; characterization and application of immobilized cells for metal removal. Sci. Rep. 2020, 10, 9491. [CrossRef]

113. do Nascimento, J.M.; de Oliveira, J.D.; Rizzo, A.C.L.; Leite, S.G.F. Biosorption Cu (II) by the yeast Saccharomyces cerevisiae. Biotechnol. Rep. (Amst) 2019, 21, e00315. [CrossRef] [PubMed]

114. Lacerda, E.C.M.; Dos Passos Galluzzi Baltazar, M.; Dos Reis, T.A.; do Nascimento, C.A.O.; Correa, B.; Gimenes, L.J. Copper biosorption from an aqueous solution by the dead biomass of Penicillium ochrochloron. Environ. Monit. Assess. 2019, 191, 247. [CrossRef] [PubMed]

115. Ali, M.M.; Bhakta, J.N. Biosorption of zinc from aqueous solution using leaves of Corchorus olitorius as a low-cost biosorbent. Water Environ. Res. 2020, 92, 821-828. [CrossRef] [PubMed]

116. Liu, X.; Han, B.; Su, C.L.; Han, Q.; Chen, K.J.; Chen, Z.Q. Optimization and mechanisms of biosorption process of $\mathrm{Zn}(\mathrm{II})$ on rape straw powders in aqueous solution. Environ. Sci. Pollut. Res. Int. 2019, 26, 32151-32164. [CrossRef]

117. Tariq, A.; Ullah, U.; Asif, M.; Sadiq, I. Biosorption of arsenic through bacteria isolated from Pakistan. Int. Microbiol. 2019, 22, 59-68. [CrossRef]

118. Li, D.; Li, R.; Ding, Z.; Ruan, X.; Luo, J.; Chen, J.; Zheng, J.; Tang, J. Discovery of a novel native bacterium of Providencia sp. with high biosorption and oxidation ability of manganese for bioleaching of heavy metal contaminated soils. Chemosphere 2020, 241, 125039. [CrossRef]

119. Noormohamadi, H.R.; Fat'hi, M.R.; Ghaedi, M.; Ghezelbash, G.R. Potentiality of white-rot fungi in biosorption of nickel and cadmium: Modeling optimization and kinetics study. Chemosphere 2019, 216, 124-130. [CrossRef]

120. Li, H.; Dong, W.; Liu, Y.; Zhang, H.; Wang, G. Enhanced Biosorption of Nickel Ions on Immobilized Surface-Engineered Yeast Using Nickel-Binding Peptides. Front. Microbiol. 2019, 10, 1254. [CrossRef]

121. Lee, K.Y.; Lee, S.H.; Lee, J.E.; Lee, S.Y. Biosorption of radioactive cesium from contaminated water by microalgae Haematococcus pluvialis and Chlorella vulgaris. J. Environ. Manag. 2019, 233, 83-88. [CrossRef]

122. Giese, E.C.; Dekker, R.F.H.; Barbosa-Dekker, A.M. Biosorption of lanthanum and samarium by viable and autoclaved mycelium of Botryosphaeria rhodina MAMB-05. Biotechnol. Prog. 2019, 35, e2783. [CrossRef]

123. Kalak, T.; Dudczak-Halabuda, J.; Tachibana, Y.; Cierpiszewski, R. Effective use of elderberry (Sambucus nigra) pomace in biosorption processes of Fe(III) ions. Chemosphere 2020, 246, 125744. [CrossRef] [PubMed]

124. Krishna Kanamarlapudi, S.L.R.; Muddada, S. Structural Changes of Bacillus subtilis Biomass on Biosorption of Iron (II) from Aqueous Solutions: Isotherm and Kinetic Studies. Pol. J. Microbiol. 2019, 68, 549-558. [CrossRef] [PubMed] 
125. Lapworth, D.J.; Baran, N.; Stuart, M.E.; Ward, R.S. Emerging organic contaminants in groundwater: A review of sources, fate and occurrence. Environ. Pollut. 2012, 163, 287-303. [CrossRef] [PubMed]

126. Garcia, J.; Garcia-Galan, M.J.; Day, J.W.; Boopathy, R.; White, J.R.; Wallace, S.; Hunter, R.G. A review of emerging organic contaminants (EOCs), antibiotic resistant bacteria (ARB), and antibiotic resistance genes (ARGs) in the environment: Increasing removal with wetlands and reducing environmental impacts. Bioresour. Technol. 2020, 307, 123228. [CrossRef] [PubMed]

127. Sun, W.; Sun, W.; Wang, Y. Biosorption of Direct Fast Scarlet 4BS from aqueous solution using the green-tide-causing marine algae Enteromorpha prolifera. Spectrochim. Acta Part A Mol. Biomol. Spectrosc. 2019, 223, 117347. [CrossRef]

128. Dada, A.O.; Adekola, F.A.; Odebunmi, E.O.; Dada, F.E.; Bello,O.M.; Akinyemi, B.A.; Bello, O.S.; Umukoro, O.G. Sustainable and low-cost Ocimum gratissimum for biosorption of indigo carmine dye: Kinetics, isotherm, and thermodynamic studies. Int. J. Phytoremediat. 2020, 1-14. [CrossRef]

129. Sunsandee, N.; Ramakul, P.; Phatanasri, S.; Pancharoen, U. Biosorption of dicloxacillin from pharmaceutical waste water using tannin from Indian almond leaf: Kinetic and equilibrium studies. Biotechnol. Rep. (Amst) 2020, 27, e00488. [CrossRef]

130. Pi, S.; Li, A.; Cui, D.; Su, Z.; Feng, L.; Ma, F.; Yang, J. Biosorption behavior and mechanism of sulfonamide antibiotics in aqueous solution on extracellular polymeric substances extracted from Klebsiella sp. J1. Bioresour. Technol. 2019, 272, 346-350. [CrossRef]

131. Ezekoye, O.M.; Akpomie, K.G.; Eze, S.I.; Chukwujindu, C.N.; Ani, J.U.; Ujam, O.T. Biosorptive interaction of alkaline modified Dialium guineense seed powders with ciprofloxacin in contaminated solution: Central composite, kinetics, isotherm, thermodynamics, and desorption. Int. J. Phytoremediat. 2020, 22, 1028-1037. [CrossRef]

132. Parlayici, S.; Pehlivan, E. Biosorption of methylene blue and malachite green on biodegradable magnetic Cortaderia selloana flower spikes: Modeling and equilibrium study. Int. J. Phytoremediat. 2020, 1-15. [CrossRef]

133. de Araujo, T.P.; Tavares, F.O.; Vareschini, D.T.; Barros, M. Biosorption mechanisms of cationic and anionic dyes in a low-cost residue from brewer's spent grain. Environ. Technol. 2020, 1-16. [CrossRef] [PubMed]

134. Silva, F.; Nascimento, L.; Brito, M.; da Silva, K.; Paschoal, W., Jr.; Fujiyama, R. Biosorption of Methylene Blue Dye Using Natural Biosorbents Made from Weeds. Materials 2019, 12, 2486. [CrossRef] [PubMed]

135. Lebron, Y.A.R.; Moreira, V.R.; de Souza Santos, L.V. Biosorption of methylene blue and eriochrome black T onto the brown macroalgae Fucus vesiculosus: Equilibrium, kinetics, thermodynamics and optimization. Environ. Technol. 2019, 1-19. [CrossRef]

136. Bouzikri, S.; Ouasfi, N.; Benzidia, N.; Salhi, A.; Bakkas, S.; Khamliche, L. Marine alga "Bifurcaria bifurcata": Biosorption of Reactive Blue 19 and methylene blue from aqueous solutions. Environ. Sci. Pollut. Res. Int. 2020, 27, 33636-33648. [CrossRef] [PubMed]

137. Grassi, P.; Reis, C.; Drumm, F.C.; Georgin, J.; Tonato, D.; Escudero, L.B.; Kuhn, R.; Jahn, S.L.; Dotto, G.L. Biosorption of crystal violet dye using inactive biomass of the fungus Diaporthe schini. Water Sci. Technol. 2019, 79, 709-717. [CrossRef]

138. Azari, A.; Noorisepehr, M.; Dehghanifard, E.; Karimyan, K.; Hashemi, S.Y.; Kalhori, E.M.; Norouzi, R.; Agarwal, S.; Gupta, V.K. Experimental design, modeling and mechanism of cationic dyes biosorption on to magnetic chitosan-lutaraldehyde composite. Int. J. Biol. Macromol. 2019, 131, 633-645. [CrossRef]

139. Deniz, F.; Yildiz, H. Taguchi DoE methodology for modeling of synthetic dye biosorption from aqueous effluents: Parametric and phenomenological studies. Int. J. Phytoremediat. 2019, 21, 1065-1071. [CrossRef]

140. Selvakumar, A.; Rangabhashiyam, S. Biosorption of Rhodamine B onto novel biosorbents from Kappaphycus alvarezii, Gracilaria salicornia and Gracilaria edulis. Environ. Pollut. 2019, 255, 113291. [CrossRef] [PubMed]

141. Liu, F.; Zhang, X.; Wang, M.; Guo, L.; Yang, Y.; Zhao, M. Biosorption of sterols from tobacco waste extract using living and dead of newly isolated fungus Aspergillus fumigatus strain LSD-1. Biosci. Biotechnol. Biochem. 2020, 84, 1521-1528. [CrossRef] [PubMed]

142. Coelho, C.M.; de Andrade, J.R.; da Silva, M.G.C.; Vieira, M.G.A. Removal of propranolol hydrochloride by batch biosorption using remaining biomass of alginate extraction from Sargassum filipendula algae. Environ. Sci. Pollut. Res. Int. 2020, 27, 16599-16611. [CrossRef] [PubMed] 
143. Bo, L.G.; Almeida, R.M.; Cardoso, C.M.M.; Zavarize, D.G.; Brum, S.S.; Mendonca, A.R.V. Acetylsalicylic acid biosorption onto fungal-bacterial biofilm supported on activated carbons: An investigation via batch and fixed-bed experiments. Environ. Sci. Pollut. Res. Int. 2019, 26, 28962-28976. [CrossRef] [PubMed]

144. Silva, A.; Coimbra, R.N.; Escapa, C.; Figueiredo, S.A.; Freitas, O.M.; Otero, M. Green Microalgae Scenedesmus Obliquus Utilization for the Adsorptive Removal of Nonsteroidal Anti-Inflammatory Drugs (NSAIDs) from Water Samples. Int. J. Environ. Res. Public Health 2020, 17, 3707. [CrossRef] [PubMed]

145. De Gisi, S.; Lofrano, G.; Grassi, M.; Notarnicola, M. Characteristics and adsorption capacities of low-cost sorbents for wastewater treatment: A review. Sustain. Mater. Technol. 2016, 9, 10-40. [CrossRef]

146. Crini, G.; Lichtfouse, E.; Wilson, L.D.; Morin-Crini, N. Conventional and non-conventional adsorbents for wastewater treatment. Environ. Chem. Lett. 2019, 17, 195-213. [CrossRef]

147. Zhu, C.; Zhai, X.; Xi, Y.; Wang, J.; Kong, F.; Zhao, Y.; Chi, Z. Progress on the development of floating photobioreactor for microalgae cultivation and its application potential. World J. Microbiol. Biotechnol. 2019, 35, 190. [CrossRef]

Publisher's Note: MDPI stays neutral with regard to jurisdictional claims in published maps and institutional affiliations.

(C) 2020 by the author. Licensee MDPI, Basel, Switzerland. This article is an open access article distributed under the terms and conditions of the Creative Commons Attribution (CC BY) license (http://creativecommons.org/licenses/by/4.0/). 